\title{
Blood-based biomarkers of inflammation in amyotrophic lateral sclerosis
}

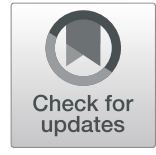

\author{
Kim A. Staats ${ }^{1}$, David R. Borchelt ${ }^{2}$, Malú Gámez Tansey ${ }^{3}$ and James Wymer ${ }^{4^{*}}$ (D)
}

\begin{abstract}
Amyotrophic Lateral Sclerosis (ALS) is a devastating neurodegenerative disease in which many processes are detected including (neuro)inflammation. Many drugs have been tested for ALS in clinical trials but most have failed to reach their primary endpoints. The development and inclusion of different types of biomarkers in diagnosis and clinical trials can assist in determining target engagement of a drug, in distinguishing between ALS and other diseases, and in predicting disease progression rate, drug responsiveness, or an adverse event. Ideally, among other characteristics, a biomarker in ALS correlates highly with a disease process in the central nervous system or with disease progression and is conveniently obtained in a peripheral tissue. Here, we describe the state of biomarkers of inflammation in ALS by focusing on peripherally detectable and cellular responses from blood cells, and provide new (combinatorial) directions for exploration that are now feasible due to technological advancements.
\end{abstract}

Keywords: Amyotrophic lateral sclerosis, Biomarker, Inflammation, Cytokines

\section{Background}

The efforts to develop an effective treatment in Amyotrophic Lateral Sclerosis (ALS), have resulted in over 40 failed drugs in clinical trials for ALS, testing a broad range of targets [1]. In most of these clinical trials, it is difficult to ascertain the reason for the failure. The drug may have failed to engage its target, had efficacy in a subgroup of patients, or the therapeutic target was not relevant to disease progression at all, or within the clinical trial duration. To promote more informative clinical trials, the Food and Drug Administration (FDA) has included the co-development of biomarkers in their ALS drug development guidance for industry (finalized September 2019), and defines a biomarker as 'a defined characteristic that is measured as an indicator of normal biological processes, pathogenic processes, or responses to an exposure or intervention, including therapeutic interventions' [2]. In this manuscript, we describe the

\footnotetext{
* Correspondence: James.Wymer@neurology.ufl.edu

${ }^{4}$ Department of Neurology, University of Florida College of Medicine, Gainesville, Florida, USA

Full list of author information is available at the end of the article
}

state of biomarkers of inflammation in ALS by focusing on peripherally detectable and cellular responses from blood cells, per FDA defined subtype of biomarker. In addition, we provide new (combinatorial) directions for exploration that are now feasible due to technological advancements.

\section{Definitions of biomarkers}

To harmonize used terminology, the Food and Drugs Administration (FDA) has defined a biomarker and seven subtypes of biomarkers through the Biomarker EndpointS and other Tools (BEST) resource [2], as the following.

\section{Biomarker}

A defined characteristic that is measured as an indicator of normal biological processes, pathogenic processes, or responses to an exposure or intervention, including therapeutic interventions. Molecular, histologic, radiographic, or physiologic characteristics are types of biomarkers. A biomarker is not an assessment of how a patient feels, functions, or survives. 


\section{Diagnostic biomarker}

A biomarker used to detect or confirm presence of a disease or condition of interest or to identify individuals with a subtype of the disease.

\section{Monitoring biomarker}

A biomarker measured serially for assessing status of a disease or medical condition or for evidence of exposure to (or effect of) a medical product or an environmental agent.

Pharmacodynamic/Response biomarker: A biomarker used to show that a biological response has occurred in an individual who has been exposed to a medical product or an environmental agent.

\section{Predictive biomarker}

A biomarker used to identify individuals who are more likely than similar individuals without the biomarker to experience a favorable or unfavorable effect from exposure to a medical product or an environmental agent.

\section{Prognostic biomarker}

A biomarker used to identify likelihood of a clinical event, disease recurrence or progression in patients who have the disease or medical condition of interest.

\section{Safety biomarker}

A biomarker measured before or after an exposure to a medical product or an environmental agent to indicate the likelihood, presence, or extent of toxicity as an adverse effect.

\section{Susceptibility/risk biomarker}

A biomarker that indicates the potential for developing a disease or medical condition in an individual who does not currently have clinically apparent disease or the medical condition.

\section{Search strategy and selection criteria}

References for this review were identified by searches of PubMed up to February 2021, and references from relevant articles. The search terms "ALS + blood + inflammation" and "Amyotrophic + blood + inflammation" were used, with recommended additions by reviewers. Phase 3 studies in Table 3 were identified by assessing clinicaltrials.gov for entries up to February 2021 that matched the search terms "ALS" (condition or disease) and "phase 3" (other terms). During filtering, studies with a recruitment status of "suspended", "terminated", or "withdrawn" were removed from assessment. The remaining studies were subsequently analyzed for the medicinal product's main target and suitability for this review. There were no language restrictions. The final reference list was generated on the basis of relevance to the topics covered in this review

\section{Introduction}

ALS is a devastating neurodegenerative disease, characterized by a progressive loss of motor neurons, paralysis, and inflammation with an average survival of 3-5 years after diagnosis. Although $\sim 5-10 \%$ of cases are familial, and $\sim 70 \%$ of the familial cases can be explained by identified gene mutations, e.g. the $C 9$ orf 72 repeat expansion $[7,8]$, most cases are of a sporadic nature whereby no other family member is known with the disease [9]. Only two drugs have received market approval in the USA, Riluzole and Edaravone, and one in the EU, Riluzole, providing only a moderate extension of patient life [10]. With the number of cases expected to rise to nearly 400,000 world-wide by 2040 [11], ALS represents a large unmet medical need for which many drugs are in development [12]. The use of validated and qualified biomarkers in ALS clinical trials could greatly increase the informative value of any conducted trial regarding whether the target was properly engaged (pharmacodynamic biomarker), the therapeutic potential of the drug or target (pharmacodynamic, prognostic biomarker), as well as assist in population stratification for likely responders to a specific treatment in this heterogeneous disease (predictive biomarker). Better biomarkers would assist in differentiating ALS from other diseases with similar presentation and the earlier diagnosis of ALS will allow patients to receive treatment sooner, as well as be eligible for clinical trials sooner (diagnostic biomarker). Furthermore, a biomarker that tracks with disease would aid in disease classification, prognostication, and assist in the perhaps personalized need for clinical intervention, as ALS phenotypes are largely heterogeneous [13].

Characteristics of an ideal biomarker for ALS include a high correlation with a disease process in the central nervous system (CNS) or with disease state / progression, stable throughout the day, high sensitivity and specificity depending on its use, and ease of obtaining samples, (e.g. blood) [14]. Biomarker research in ALS has led to the identification of $p 75^{\mathrm{ECD}}$ from urine [15], phosphorylated neurofilament heavy ( $\mathrm{pNfH}$ ) in cerebrospinal fluid (CSF) [16], and neurofilament light (NfL) in serum [17] as diagnostic, prognostic, and pharmacodynamic biomarkers. However, these three are not unique to ALS, while potentially having a role in prognostication and disease monitoring, these biomarkers have low specificity for ALS. These biomarkers are also dependent on axonal loss and may reflect later stages of degeneration and therefore miss the spectrum of disease activity. Finally, CSF extraction for pNfH, while useful for diagnosis, does involve what can be a difficult procedure for some patients and serial lumbar puncture is unrealistic 
outside of clinical research. To develop an ideal biomarker for ALS a more rounded test or panel of tests is needed that is easy to reproduce, addresses the spectrum of disease, and is simple to obtain multiple specimens. To address the spectrum of disease activity this biomarker or group of biomarkers should focus on neuronal loss as well as other disease mechanisms.

Inflammation occurs in the CNS during ALS, and is also detected peripherally in blood as altered immune cell population abundance and released factors [18-20]. The potential causative or disease driving role of this inflammation in ALS is not fully clear, as there are studies that support both a primary or secondary role during ALS disease progression. Inflammatory biomarkers could reflect that bridge to other disease activity and, in combination with assays of neuronal degeneration, provide a better sense of disease subtypes and disease activity. In this review, we discuss the state of biomarkers of inflammation in ALS, focusing on peripherally detectable and cellular responses from blood cells, and provide new (combinatorial) directions for exploration that are now feasible due to technological advancements. We start with potential diagnostic biomarkers of inflammation in ALS, proceeding to prognostic biomarkers and conclude with how other biomarkers, pharmacodynamic and predictive, can assist in the design and interpretation of clinical trials in ALS.

\section{Diagnostic biomarkers}

The diagnosis of ALS depends on the exclusion of other disease mimics first, and often takes over 12 months [21]. Hereditary neuropathy, acquired neuropathies, Myasthenia Gravis (MG), and central demyelinating disease can present similar to ALS and be difficult to fully exclude. This is compounded even more by the varied presentation of ALS (bulbar vs. limb onset, primary lateral sclerosis vs. progressive muscle atrophy, young onset vs. old onset), as well as by the addition of nondiagnostic characteristics such as flail-arm syndrome and frontotemporal involvement [13]. A robust and specific ALS diagnostic biomarker would aid to decrease the uncertainty and the time to diagnosis for all patients, allowing for earlier interventions and increasing the time window of eligibility to participate in clinical trials. With the exception of a few of these biomarkers (e.g. acetylcholine receptor antibodies in MG and MRI in multiple sclerosis) a specific and sensitive biomarker has been difficult to identify for these conditions, and even more so with (neuro) inflammation not solely occurring in ALS. As a result, therapeutic trials are based primarily on clinical scales and require longer observation to assess efficacy, thereby increasing cost and slowing drug development [22-25]. The initial hurdle for a diagnostic biomarker is to distinguish between ALS and controls (as the studies in Table 1 were designed to detect), but in practical use the biomarker(s) need to distinguish between ALS and other ALS-mimicking diseases, e.g. those that are excluded at diagnosis.

Inflammation as a biomarker in ALS, historically, was studied in context of the spinal cord disease. Inflammation-based biomarkers started with candidatebased analyses of cerebrospinal fluid (CSF), assessing cell populations such as lymphocytic infiltrates and secreted factors of the CNS [19]. The detection of peripheral inflammation in blood samples of ALS patients [20] led to the assessment of these blood-based markers of inflammation as potentially diagnostic biomarkers. Initially, studies were conducted on candidate-based cell populations, such as the increased neutrophil-to-lymphocyte ratio in ALS [28], which has potential as a diagnostic biomarker in multiple sclerosis [62], and soluble factors (Table 1). In-depth immunophenotyping by flow cytometry identified 116 distinct blood-derived cell populations of which 32 populations were altered, including elevated cell counts of granulocytes, NK cells and T cells in ALS samples compared to controls [55], and was confirmed by others [27]. Technological advancement led to the multiplexing of many soluble factors on the same sample simultaneously, but this also did not identify a robust ALS diagnostic biomarker (as of yet). Although candidate-based analyses suggest inflammatory pathways and factors (e.g. cytokines) may be differentially expressed in ALS, the variability among the reports of these measurements is high, with the most commonly measured cytokines are reported, in different studies, to be upregulated and/or downregulated and/or unaltered in ALS, including C-reactive protein (CRP) [26, 28, 32], interleukin 6 (IL-6) [27, 29, 33-35, 38-40, 56], IL-8 [32, $34,38,39,44,56]$, tumor necrosis factor (TNF) [27, 29, $31,32,34,38,39,56]$, IL-1 $\beta$ [27, 31, 32, 38, 40], IL-17 [27, 32, 40], IL-33 [40, 41], IL-10 [27, 32, 34, 39], monocyte chemoattractant protein 1 (MCP-1) [34, 38, 44, 47, 48], and interferon gamma (IFNY) [27, 31, 34, 45, 56] (Table 1). Please note that many of these studies are underpowered 'pilot' studies that require replication. To minimize inter-sample variability simultaneous combinations of single factors were assessed to strengthen the diagnostic value of the combined biomarkers, e.g. IL-2 and IL-6 [34], or microRNA (miRNA) pairs (ratios) [36]. (Please note, that these specific examples of combined markers results have not (yet) been replicated.)

With many of the subpopulations of blood cells producing different expression levels of genes or soluble factors, these analyses in blood provide an averaged data point, losing the cell-type specific resolution of the obtained data. This may partly explain why there is no established diagnostic biomarker for ALS (yet) by using single factor analyses, in addition to the other possible 
Table 1 Blood-based diagnostic biomarkers of inflammation in ALS

\begin{tabular}{|c|c|c|c|c|c|}
\hline $\begin{array}{l}\text { Measured } \\
\text { biomarker(s) }\end{array}$ & $\begin{array}{l}\text { Tissue and detection } \\
\text { method }\end{array}$ & $\begin{array}{l}\text { Mean disease duration } \\
\text { at sample donation }\end{array}$ & Number of samples & $\begin{array}{l}\text { Potential Diagnostic } \\
\text { Value }\end{array}$ & $\begin{array}{l}\text { Study Reference } \\
\text { Clinical Trial ID }\end{array}$ \\
\hline \multicolumn{6}{|l|}{ Cell populations } \\
\hline $\begin{array}{l}\text { Monocyte } \\
\text { subpopulations }\end{array}$ & $\begin{array}{l}\text { Monocyte isolation kit from } \\
\text { peripheral blood, and flow } \\
\text { cytometry }\end{array}$ & Not reported & $\begin{array}{l}n=68 \text { ALS (1st cohort) } \\
n=55 \text { controls ( } 1 \text { st cohort) } \\
n=100 \text { ALS ( } 2 \text { nd cohort) } \\
n=60 \text { controls ( } 2 \text { nd cohort) }\end{array}$ & $\begin{array}{l}\text { - CD14-/low/CD16+ } \\
\text { monocytes decreased in } \\
\text { ALS }\end{array}$ & $\begin{array}{l}\text { Beers et al., } 2020 \\
\text { [26] }\end{array}$ \\
\hline $\begin{array}{l}\text { Subpopulations } \\
\text { of T cells, B } \\
\text { cells, natural } \\
\text { killer cells, and } \\
\text { antigen } \\
\text { presenting cells }\end{array}$ & Peripheral blood and FACS & 2.48 years & $\begin{array}{l}n=73 \text { ALS } \\
n=48 \text { controls }\end{array}$ & $\begin{array}{l}\text { - increased Th1 and Th17 } \\
\text { cells in ALS } \\
\text { - decreased Th2 and Treg } \\
\text { cells in ALS } \\
\text { - increased NK cells and } \\
\text { monocytes in ALS }\end{array}$ & $\begin{array}{l}\text { Jin et al., } 2020 \\
\text { [27] }\end{array}$ \\
\hline $\begin{array}{l}\text { neutrophil-to- } \\
\text { lymphocyte } \\
\text { ratio (NLR) }\end{array}$ & From whole blood & Not reported & $\begin{array}{l}n=80 \text { ALS } \\
n=80 \text { matched controls }(n= \\
41 \text { ALS and } n=41 \text { matched } \\
\text { controls at follow-up } 3-6 \mathrm{~m} \\
\text { after initial donation; } n=22 \\
\text { ALS patients and } n=22 \\
\text { matched controls at the third } \\
\text { donation at least } 3 \text { months } \\
\text { after the second) }\end{array}$ & $\begin{array}{l}\text { - NLR was consistently } \\
\text { elevated in ALS samples }\end{array}$ & $\begin{array}{l}\text { Keizman et al., } \\
2009 \text { [28] }\end{array}$ \\
\hline \multicolumn{6}{|c|}{ Candidate-based soluble factor analysis } \\
\hline $\begin{array}{l}\text { IL-2, IL-6, IL-10, } \\
\text { IFN- } \gamma \text {, and TNF }\end{array}$ & Plasma, BioPlex & 21.37 months (median) & $\begin{array}{l}n=79 \text { ALS } \\
n=79 \text { controls }\end{array}$ & $\begin{array}{l}\text { - all measured cytokines } \\
\text { were increased in ALS }\end{array}$ & $\begin{array}{l}\text { Tortelli et al., } \\
2020[29]\end{array}$ \\
\hline $\begin{array}{l}\text { CD14, LBP and } \\
\text { CRP }\end{array}$ & Serum; ELISAs & Not reported & $\begin{array}{l}\mathrm{n}=68 \text { ALS (1st cohort) } \\
n=55 \text { controls }(1 \mathrm{st} \text { cohort) } \\
n=100 \text { ALS ( } 2 \text { nd cohort) } \\
n=60 \text { controls ( } 2 \text { nd cohort) }\end{array}$ & $\begin{array}{l}\text { - soluble CD14 increased in } \\
\text { ALS (both cohorts) } \\
\text { - LBP increased in ALS (both } \\
\text { cohorts) } \\
\text { - CRP increased in ALS (both } \\
\text { cohorts) }\end{array}$ & $\begin{array}{l}\text { Beers et al., } 2020 \\
{[26]}\end{array}$ \\
\hline $\begin{array}{l}\text { IL-1b, IL-6, IL-10, } \\
\text { IL-12, TNF,IFN- } \gamma_{1} \\
\text { IL17a, and IL-23 }\end{array}$ & Serum; ELISAs & 2.48 years & $\begin{array}{l}n=73 \mathrm{ALS} \\
n=48 \text { controls }\end{array}$ & $\begin{array}{l}\text { - increased IL-1b, IL-6, and } \\
\text { IFN- } \gamma \text { in ALS } \\
\text { - decreased IL-10 in ALS } \\
\text { - no difference in TNF, IL-12, } \\
\text { IL-17a, and IL-23 }\end{array}$ & $\begin{array}{l}\text { Jin et al., } 2020 \\
\text { [27] }\end{array}$ \\
\hline CD5L, Ficolin-3 & Plasma; ELISAs & 739.9 months (median) & $\begin{array}{l}n=37 \text { ALS } \\
n=30 \text { controls }\end{array}$ & $\begin{array}{l}\text { CD5L and Ficolin-3 are in- } \\
\text { creased in ALS }\end{array}$ & $\begin{array}{l}\text { Mohanty et al., } \\
2020 \text { [30] }\end{array}$ \\
\hline $\begin{array}{l}\text { IL-2, IL-1b, TNF, } \\
\text { IFN- } \gamma \text { and IL-4 }\end{array}$ & Serum; ELISAs & 40.4 months & $\begin{array}{l}n=35 \mathrm{ALS} \\
n=30 \text { controls }\end{array}$ & $\begin{array}{l}\text { - increased IL-4 and IL-1b in } \\
\text { ALS } \\
\text { - decreased IFN- } \gamma \text { in ALS } \\
\text { - no difference in IL-2 and } \\
\text { TNF }\end{array}$ & $\begin{array}{l}\text { Polverino et al., } \\
2020 \text { [31] }\end{array}$ \\
\hline $\begin{array}{l}\text { MCP-1, eotaxin- } \\
\text { 1, IL-18, TNF, } \\
\text { CRP, IL-1, } \\
\text { sTREM2 }\end{array}$ & Plasma; MSD assay & Not reported & $\begin{array}{l}n=108 \text { ALS } \\
n=41 \text { controls } \\
(n=85 \text { ALS with samples } 2+ \\
\text { visits) }\end{array}$ & $\begin{array}{l}\text { - MCP-1 and IL-18 are in- } \\
\text { creased in ALS } \\
\text { - sTREM2 is increased in ALS }\end{array}$ & $\begin{array}{l}\text { Huang et a } a_{i \cdot} \\
2020[32] \\
\text { NCT01495390 }\end{array}$ \\
\hline IL-6 & Plasma; Chemokine assay & 25.7 months & $\begin{array}{l}n=82 \mathrm{ALS} \\
n=43 \text { controls }\end{array}$ & $\begin{array}{l}\text { Not upregulated in ALS } \\
\text { (trend) }\end{array}$ & $\begin{array}{l}\text { Pronto-Laborinho } \\
\text { et al., } 2019 \text { [33] }\end{array}$ \\
\hline $\begin{array}{l}\text { IP-10, MCP-1, } \\
\text { MIG, RANTES, } \\
\text { IL-2, IL-4, IL-6, } \\
\text { IL-8, IL-10, IL- } \\
\text { 17a, TNF, IGF-g, } \\
\text { sTNFR1, sTNFR2 }\end{array}$ & $\begin{array}{l}\text { Plasma; cytometric bead } \\
\text { array and ELISA }\end{array}$ & 3 years & $\begin{array}{l}\mathrm{n}=68 \mathrm{ALS} \\
n=62 \text { controls over the first } \\
\text { time point. } \\
n=24 \mathrm{ALS} \text { at the second } \\
\text { time point ( } 6-12 \text { months } \\
\text { later) }\end{array}$ & $\begin{array}{l}\text { IL-6 + IL-8: upregulated in } \\
\text { ALS } \\
\text { IL-2 (low) and IL-6 (high) pre- } \\
\text { dict ALS diagnosis }\end{array}$ & $\begin{array}{l}\text { Prado et al., } 2018 \\
\text { [34] }\end{array}$ \\
\hline $\begin{array}{l}\text { Gene } \\
\text { expression of } \\
45 \text { genes }\end{array}$ & Serum; individual RT-qPCRs & $\begin{array}{l}\text { Within the first } 2 \\
\text { months of diagnosis }\end{array}$ & $\begin{array}{l}n=22 \text { sALS } \\
n=13 \text { controls }\end{array}$ & $\begin{array}{l}\text { - ITGB2, INPP5D, SELL, ICAM1, } \\
\text { MMP9 and TIMP2 are } \\
\text { upregulated in ALS } \\
\text { - CCL5, CXC5R, IL10, TGFB2, } \\
\text { IL10RA, IL-6, CD2 and TRBC1 } \\
\text { are downregulated in ALS }\end{array}$ & $\begin{array}{l}\text { Andres-Benito } \\
\text { et al., } 2017 \text { [35] }\end{array}$ \\
\hline $\begin{array}{l}\text { Gene } \\
\text { expression of } \\
37 \text { brain- } \\
\text { enriched and }\end{array}$ & Plasma; individual RT-qPCRs & 1.8 years & $\begin{array}{l}n=50 \mathrm{ALS} \\
n=50 \mathrm{FTD} \\
\mathrm{n}=50 \mathrm{AD} \\
\mathrm{n}=50 \mathrm{PD}\end{array}$ & $\begin{array}{l}\text { miR-206/miR-31 and miR- } \\
\text { 206/ miR-125b and miR-99/ } \\
\text { miR-338-3p most effectively } \\
\text { differentiate between ALS }\end{array}$ & $\begin{array}{l}\text { Sheinerman } \\
\text { et al., } 2017 \text { [36] }\end{array}$ \\
\hline
\end{tabular}


Table 1 Blood-based diagnostic biomarkers of inflammation in ALS (Continued)

\begin{tabular}{|c|c|c|c|c|c|}
\hline $\begin{array}{l}\text { Measured } \\
\text { biomarker(s) }\end{array}$ & $\begin{array}{l}\text { Tissue and detection } \\
\text { method }\end{array}$ & $\begin{array}{l}\text { Mean disease duration } \\
\text { at sample donation }\end{array}$ & Number of samples & $\begin{array}{l}\text { Potential Diagnostic } \\
\text { Value }\end{array}$ & $\begin{array}{l}\text { Study Reference } \\
\text { Clinical Trial ID }\end{array}$ \\
\hline $\begin{array}{l}\text { inflammation- } \\
\text { associated } \\
\text { microRNAs }\end{array}$ & & & $\mathrm{n}=50$ controls & and control & \\
\hline CC-16 & Plasma; ELISA & 27 months & $\begin{array}{l}n=81 \text { ALS } \\
n=30 \text { controls }\end{array}$ & Upregulated in ALS & $\begin{array}{l}\text { Pronto-Laborinho } \\
\text { et al., } 2017 \text { [37] }\end{array}$ \\
\hline $\begin{array}{l}\text { TNF, MCP-1, IL6, } \\
\text { IL8, IL2, IFN-Y, } \\
\text { IL1-beta, IL10, } \\
\text { IL4, IL5, IL17, } \\
\text { TNFR1, ELAM-1 }\end{array}$ & $\begin{array}{l}\text { Plasma; different per } \\
\text { individual dataset ( } 25 \\
\text { studies) }\end{array}$ & $\begin{array}{l}\text { different per individual } \\
\text { dataset ( } 25 \text { studies) }\end{array}$ & $\begin{array}{l}\text { pooled } n=812 \text { ALS } \\
\text { pooled } n=639 \text { controls }\end{array}$ & $\begin{array}{l}\text { TNF, TNFR-1, IL-6, IL-1 } 1 \beta \text {, and } \\
\text { IL-8 levels were elevated in } \\
\text { ALS. }\end{array}$ & Hu et al., 2017 \\
\hline $\begin{array}{l}\text { TNF, IL-8, IL-6, } \\
\text { IL-10 }\end{array}$ & Serum; multiplex assay & Not reported & $\begin{array}{l}n=19 \text { ALS } \\
n=10 \text { controls }\end{array}$ & $\begin{array}{l}\text { - IL- } 6 \text { was increased in ALS. } \\
\text { - IL-8 was increased in ALS. }\end{array}$ & $\begin{array}{l}\text { Blasco et al., } \\
2016 \text { [39] }\end{array}$ \\
\hline $\begin{array}{l}\text { IL-1ß, IL-18, IL- } \\
33, \text { IL-37, IL-1Ra, } \\
\text { sIL-1R2, IL-18BP, } \\
\text { sIL-1R4 }\end{array}$ & Serum; individual ELISAs & 11.32 months & $\begin{array}{l}n=144 \text { sALS } \\
n=40 \text { controls }\end{array}$ & $\begin{array}{l}\text { - IL-18 was increased in ALS. } \\
\text { - IL-18BP was increased in } \\
\text { ALS. }\end{array}$ & $\begin{array}{l}\text { Italiani et al., } \\
2014 \text { [40] }\end{array}$ \\
\hline $\begin{array}{l}\text { IL-33, soluble } \\
\text { ST2 }\end{array}$ & Serum; individual ELISAs & Not reported & $\begin{array}{l}n=42 \text { ALS } \\
n=38 \text { controls }\end{array}$ & $\begin{array}{l}\text { - IL-33 was increased in ALS } \\
\text { - soluble ST2 was decreased } \\
\text { in ALS }\end{array}$ & $\begin{array}{l}\text { Lin et al., } 2012 \\
\text { [41] }\end{array}$ \\
\hline IL-17A & Serum; individual ELISA & 23.4 months & $\begin{array}{l}n=32 \mathrm{ALS} \\
n=14 \text { controls }\end{array}$ & IL-17A was increased in ALS. & $\begin{array}{l}\text { Fiala et al., } 2010 \\
\text { [42] }\end{array}$ \\
\hline $\begin{array}{l}\text { kynurenine } \\
\text { pathway } \\
\text { (tryptophan, } \\
\text { picolinic acid) }\end{array}$ & $\begin{array}{l}\text { Serum; HPLC, gas } \\
\text { chromatography mass } \\
\text { spectrometry }\end{array}$ & Not reported & $\begin{array}{l}n=140 \text { ALS } \\
n=35 \text { controls }\end{array}$ & $\begin{array}{l}\text { - TRP and KYN is increased } \\
\text { ALS } \\
\text { - PIC is decreased in ALS }\end{array}$ & $\begin{array}{l}\text { Chen et al., } 2010 \\
\text { [43] }\end{array}$ \\
\hline $\begin{array}{l}\text { eotaxin, } \\
\text { eotaxin-3, IL-8, } \\
\text { IP-10, MCP-1, } \\
\text { MCP-4, MDC, } \\
\text { MIP-1b, TARC }\end{array}$ & $\begin{array}{l}\text { Serum; solid-phase sandwich } \\
\text { immuno-assay }\end{array}$ & Not reported & $\begin{array}{l}n=20 \mathrm{ALS} \\
n=20 \text { controls (non-ALS } \\
\text { neurologic) }\end{array}$ & No differences. & $\begin{array}{l}\text { Kuhle et al., } 2009 \\
\text { [44] }\end{array}$ \\
\hline $\begin{array}{l}\text { TNF, IFN- } \gamma \text {, and } \\
\text { NO }\end{array}$ & $\begin{array}{l}\text { Serum; individual ELISAs and } \\
\text { NO by determining nitrite } \\
\text { and nitrate levels }\end{array}$ & 12 months & $\begin{array}{l}n=22 \mathrm{ALS} \\
n=20 \text { controls }\end{array}$ & $\begin{array}{l}\text { TNF, IFN- } \gamma \text {, and NO were all } \\
\text { increased in ALS }\end{array}$ & $\begin{array}{l}\text { Babu et al., } 2008 \\
{[45]}\end{array}$ \\
\hline RANTES & Serum; individual ELISA & Not reported & $\begin{array}{l}n=20 \text { ALS } \\
n=14 \text { NIND } \\
n=13 \text { controls }\end{array}$ & $\begin{array}{l}\text { RANTES was increased in ALS } \\
\text { serum }\end{array}$ & $\begin{array}{l}\text { Rentzos et al., } \\
2008 \text { [46] }\end{array}$ \\
\hline MCP-1 & Serum; individual ELISA & 19.4 months & $\begin{array}{l}n=27 \mathrm{ALS} \\
n=30 \mathrm{NIND}\end{array}$ & MCP-1 was increased in ALS & $\begin{array}{l}\text { Baron et al., } 2005 \\
\text { [47] }\end{array}$ \\
\hline MCP-1 & Serum; individual ELISA & 8 months (median) & $\begin{array}{l}n=29 \mathrm{ALS} \\
n=11 \text { controls }\end{array}$ & $\begin{array}{l}\text { MCP-1 was not altered in } \\
\text { ALS }\end{array}$ & $\begin{array}{l}\text { Wilms et al., } 2005 \\
\text { [48] }\end{array}$ \\
\hline $\begin{array}{l}\text { wide-range C- } \\
\text { reactive protein } \\
\text { (wrCRP) }\end{array}$ & From whole blood & Not reported & $\begin{array}{l}n=80 \text { ALS } \\
n=80 \text { matched controls }\end{array}$ & $\begin{array}{l}\text { - wrCRP was consistently } \\
\text { elevated in ALS samples }\end{array}$ & $\begin{array}{l}\text { Keizman et al., } \\
2009 \text { [28] }\end{array}$ \\
\hline \multicolumn{6}{|c|}{ Unbiased analyses of serum or plasma } \\
\hline $\begin{array}{l}\text { miRNA gene } \\
\text { expression }\end{array}$ & $\begin{array}{l}\text { Plasma; next generation } \\
\text { sequencing on neural- } \\
\text { enriched extracellular } \\
\text { vesicles }\end{array}$ & Not reported & $\begin{array}{l}n=10+10 \text { (replication set) } \\
\text { ALS } \\
n=10+10 \text { (replication set) } \\
\text { controls }\end{array}$ & $\begin{array}{l}\text { Eight miRNAs were } \\
\text { differentially expressed } \\
\text { between ALS samples and } \\
\text { controls after replication. This } \\
\text { included miR-146a-5p, which } \\
\text { was upregulated in ALS sam- } \\
\text { ples and is associated with } \\
\text { inflammation (monocytes) } \\
\text { [49]. }\end{array}$ & $\begin{array}{l}\text { Banack et al.; } \\
2020 \text { [50]Some } \\
\text { samples from } \\
\text { NCT03580616. }\end{array}$ \\
\hline $\begin{array}{l}\text { Protein } \\
\text { abundance } \\
\text { detectable by } \\
\text { mass } \\
\text { spectrometry }\end{array}$ & Plasma; mass spectrometry & 747 months (median) & $\begin{array}{l}n=42 \text { ALS } \\
n=18 \text { controls }\end{array}$ & $\begin{array}{l}30 \text { proteins are differentially } \\
\text { detected between ALS and } \\
\text { controls. IPA analysis } \\
\text { identified two networks of } \\
\text { interacting proteins that } \\
\text { differ between ALS and } \\
\text { controls; IL-1 and NFkB. }\end{array}$ & $\begin{array}{l}\text { Xu et al., } 2018 \\
\text { [51] }\end{array}$ \\
\hline
\end{tabular}


Table 1 Blood-based diagnostic biomarkers of inflammation in ALS (Continued)

\begin{tabular}{|c|c|c|c|c|c|}
\hline $\begin{array}{l}\text { Measured } \\
\text { biomarker(s) }\end{array}$ & $\begin{array}{l}\text { Tissue and detection } \\
\text { method }\end{array}$ & $\begin{array}{l}\text { Mean disease duration } \\
\text { at sample donation }\end{array}$ & Number of samples & $\begin{array}{l}\text { Potential Diagnostic } \\
\text { Value }\end{array}$ & $\begin{array}{l}\text { Study Reference } \\
\text { Clinical Trial ID }\end{array}$ \\
\hline \multicolumn{6}{|c|}{ Blood-derived cells, in vitro assays } \\
\hline $\begin{array}{l}\text { Transcriptomic } \\
\text { analysis }\end{array}$ & $\begin{array}{l}\text { Gene expression of blood } \\
\text { monocyte-derived macro- } \\
\text { phages, by RNAseq and RT- } \\
\text { qPCR }\end{array}$ & Not reported & $\begin{array}{l}n=5 \text { controls } \\
n=5 \text { sALS } \\
n=5 \text { C9-ALS }\end{array}$ & $\begin{array}{l}\text { - Increased type I interferon } \\
\text { signature (pathway analysis) } \\
\text { - increased gene expression } \\
\text { of MX1, OASL, OAS2, IF44L }\end{array}$ & $\begin{array}{l}\text { McCauley et al., } \\
2020 \text { [52] }\end{array}$ \\
\hline $\begin{array}{l}\text { Cell surface } \\
\text { expression of } \\
\text { VLA4, TLR4, } \\
\text { CXCR3, CCR5, } \\
\text { CXCR4, IFN- } \gamma_{1} \\
\text { CCR2, CD11B }\end{array}$ & $\begin{array}{l}\text { Flow cytometry on blood- } \\
\text { isolated T-cells, B-cells, } \\
\text { monocytes, and NK cells }\end{array}$ & Not reported & $\begin{array}{l}n=10 \text { ALS } \\
n=10 \text { controls }\end{array}$ & $\begin{array}{l}\text { - CXCR4, CXCR3, CCR2, CCR5 } \\
\text { increased on ALS T-cells. } \\
\text { - CD11B, CCR2 decreased on } \\
\text { ALS monocytes } \\
\text { - The combination of the } \\
\text { analyzed markers could } \\
\text { significantly predict the } \\
\text { categorization into ALS or } \\
\text { healthy donors, with CXCR3 } \\
\text { and CCR5 on T cells } \\
\text { comprising the strongest } \\
\text { predictors. }\end{array}$ & $\begin{array}{l}\text { Perner et al., } \\
2018[53]\end{array}$ \\
\hline $\begin{array}{l}\text { Number of } \\
\text { migrating cells }\end{array}$ & $\begin{array}{l}\text { Boyden chamber. All cells } \\
\text { migrated to the lower well } \\
\text { after } 2.5 \mathrm{~h} \text { were stained } \\
\text { using lineage antibody and } \\
\text { counted by flow cytometry. }\end{array}$ & Not reported & $\begin{array}{l}n=10 \text { ALS } \\
n=10 \text { controls }\end{array}$ & $\begin{array}{l}\text { More ALS CD } 45+\text { cells } \\
\text { chemotaxis with IP-10 } \\
\text { chemoattractant. }\end{array}$ & $\begin{array}{l}\text { Perner et al., } \\
2018 \text { [53] }\end{array}$ \\
\hline $\begin{array}{l}\text { Frequency of } \\
\text { myeloid } \\
\text { dendritic cells }\end{array}$ & $\begin{array}{l}\text { Flow cytometry } \\
\left(\mathrm{CD} 1 \mathrm{C}^{\text {high }} \text { CD19-) }\right.\end{array}$ & Not calculated & $\begin{array}{l}n=20 \text { ALS } \\
n=10 \text { healthy donors }\end{array}$ & $\begin{array}{l}\text { - Less circulating myeloid } \\
\text { dendritic cells in ALS. } \\
\text { - Increased CD62L expression } \\
\text { on circulating myeloid } \\
\text { dendritic cells in ALS. }\end{array}$ & $\begin{array}{l}\text { Rusconi et al., } \\
2017 \text { [54] }\end{array}$ \\
\hline $\begin{array}{l}\text { Concentrations } \\
\text { of TNF, IL-1 } 13, \text { IL- } \\
6, I L-12 \mathrm{p} 40, \mathrm{IL}-8 \text {, } \\
\text { CCL2 and IL-10 } \\
\text { in BDCA1+ DC } \\
\text { supernatants }\end{array}$ & $\begin{array}{l}\text { Circulating myeloid dendritic } \\
\text { (CD1chigh) cells stimulated }^{\text {hitc }} \\
\text { with LPS. }\end{array}$ & Not calculated & $\begin{array}{l}n=52 \text { ALS } \\
n=36 \text { healthy donors } \\
n=25 \text { other neurological } \\
\text { controls. }\end{array}$ & $\begin{array}{l}\text { Higher levels of IL- } 8 \text { and } \\
\text { CCL-2 upon LPS- stimulation } \\
\text { in ALS dendritic cells }\end{array}$ & $\begin{array}{l}\text { Rusconi et al., } \\
2017 \text { [54] }\end{array}$ \\
\hline $\begin{array}{l}116 \text { leukocyte } \\
\text { populations and } \\
\text { phenotypes } \\
\text { from } \\
\text { lymphocytes, } \\
\text { monocytes, and } \\
\text { granulocytes }\end{array}$ & $\begin{array}{l}\text { Peripheral blood } \\
\text { immunophenotyping by } \\
\text { flow cytometry }\end{array}$ & 21.6 months & $\begin{array}{l}n=80 \text { ALS } \\
n=50 \text { controls }\end{array}$ & $\begin{array}{l}\text { - } 32 \text { leukocyte phenotypes } \\
\text { altered in ALS } \\
\text { - elevated cell counts of } \\
\text { granulocytes, NK cells and T } \\
\text { cells in ALS } \\
\text { - ALS patients were clustered } \\
\text { into a profile distinct from } \\
\text { controls primarily due to } \\
\text { differences in multiple T } \\
\text { cell phenotypes, CD3 CD56 } \\
\text { T cells and HLA-DR on } \\
\text { monocytes. }\end{array}$ & $\begin{array}{l}\text { Gustafson et al., } \\
2017 \text { [55] }\end{array}$ \\
\hline $\begin{array}{l}\text { Transcriptomic } \\
\text { analysis }\end{array}$ & $\begin{array}{l}\text { RNA sequencing of blood } \\
\text { monocytes }\end{array}$ & Not reported & $\begin{array}{l}\mathrm{n}=43 \mathrm{ALS} \\
\mathrm{n}=22 \text { controls }\end{array}$ & $\begin{array}{l}\text { ALS monocytes } \\
\text { demonstrated a unique } \\
\text { inflammation-related gene } \\
\text { expression profile, the most } \\
\text { prominent of which, includ- } \\
\text { ing IL1B, IL8, FOSB, CXCL1, } \\
\text { and CXCL2 }\end{array}$ & $\begin{array}{l}\text { Zhao et al., } 2017 \\
\text { [56] }\end{array}$ \\
\hline $\begin{array}{l}\text { IL1-b, IL-6, IL-8, } \\
\text { IL-10, GM-CSF, } \\
\text { and TNF and } \\
\text { TGF-b1, -b2, } \\
\text { and -b3 }\end{array}$ & $\begin{array}{l}\text { By Luminex XMAP on } \\
\text { supernatants from PBMCs or } \\
\text { macrophages cultured } \\
\text { overnight (non-stimulated, } \\
\text { and SOD1-stimulated) }\end{array}$ & Not reported & 1 discordant twin pair & $\begin{array}{l}\text { - In non-stimulated condi- } \\
\text { tions the supernatants from } \\
\text { the ALS PBMCs increased } \\
\text { IL-6, TNF, and IL-1. }\end{array}$ & $\begin{array}{l}\text { Lam et al., } 2016 \\
\text { [57] }\end{array}$ \\
\hline $\begin{array}{l}\text { Immune and } \\
\text { cytokine } \\
\text { profiling }\end{array}$ & $\begin{array}{l}\text { freshly collected, un- } \\
\text { stimulated cells by flow cy- } \\
\text { tometry, on peripheral } \\
\text { monocytes and T } \\
\text { lymphocytes. }\end{array}$ & 2.4 years & $\begin{array}{l}\mathrm{n}=24 \mathrm{ALS} \\
\mathrm{n}=25 \text { controls }\end{array}$ & $\begin{array}{l}\text { Th1-, Th17-, and IL-6-driven } \\
\text { inflammation increased in } \\
\text { ALS. }\end{array}$ & $\begin{array}{l}\text { Saresella et al., } \\
2013 \text { [58] }\end{array}$ \\
\hline $\begin{array}{l}90 \text { inflammatory } \\
\text { genes }\end{array}$ & $\begin{array}{l}\text { qPCR analysis from isolated } \\
\text { PBMCs }\end{array}$ & 25.4 months & $\begin{array}{l}n=10 \text { ALS } \\
n=4 \text { controls }\end{array}$ & $\begin{array}{l}\text { - 50\% of the ALS patients } \\
\text { had 'strong inflammation' } \\
\text { (upregulation of IL-1, IL-6, }\end{array}$ & $\begin{array}{l}\text { Fiala et al., } 2013 \\
\text { [59] No NCT } \\
\text { reported }\end{array}$ \\
\hline
\end{tabular}


Table 1 Blood-based diagnostic biomarkers of inflammation in ALS (Continued)

\begin{tabular}{|c|c|c|c|c|c|}
\hline $\begin{array}{l}\text { Measured } \\
\text { biomarker(s) }\end{array}$ & $\begin{array}{l}\text { Tissue and detection } \\
\text { method }\end{array}$ & $\begin{array}{l}\text { Mean disease duration } \\
\text { at sample donation }\end{array}$ & Number of samples & $\begin{array}{l}\text { Potential Diagnostic } \\
\text { Value }\end{array}$ & $\begin{array}{l}\text { Study Reference } \\
\text { Clinical Trial ID }\end{array}$ \\
\hline & & & & $\begin{array}{l}\text { IL23a, PTGS2, MMP1, CCL20, } \\
\text { CXCL3, CXCL5 and CXCR4; } \\
\text { downregulation of CXCL9, } \\
\text { CXCL10, and CXCL11), the } \\
\text { other 50\% had 'weak } \\
\text { inflammation'. } \\
\text { - all ALS patients had an 'ALS } \\
\text { signature' with 4-fold in- } \\
\text { crease of MMP1, CCL7, } \\
\text { CCL13 and CCL24. }\end{array}$ & \\
\hline $\begin{array}{l}\text { IL-1b, IL-2, IL-4, } \\
\text { IL-5, IL-6, IL-7, } \\
\text { IL-8, IL-10, IL-12, } \\
\text { IL-13, IFN- }{ }^{2}, \text { GM- } \\
\text { CSF, TNF }\end{array}$ & $\begin{array}{l}\text { PBMC cultures, non- } \\
\text { stimulated and stimulated } \\
\text { with SOD1 protein, superna- } \\
\text { tants analyzed by R\&D Sys- } \\
\text { tems High Sensitivity Human } \\
\text { Inflammation Multiplex-Kit }\end{array}$ & 26.9 months & $\begin{array}{l}\mathrm{n}=8 \text { sALS } \\
\mathrm{n}=4 \text { controls } \\
\mathrm{n}=1 \text { unaffected twin of sALS } \\
\text { patient }\end{array}$ & $\begin{array}{l}\text { - } 4 \text { sALS patients had } \\
\text { increased expression of } \\
\text { TLR2 and CD14; ALOX5, } \\
\text { PTGS2 and MMP1; IL1a, } \\
\text { IL1 } \beta \text {, IL6, IL36G, IL8 and } \\
\text { TNF; CCL3, CCL20, CXCL2, } \\
\text { CXCL3 and CXCL5. } \\
\text { - } 4 \text { sALS patients had a } \\
\text { decrease in the expression } \\
\text { of PPARG, PPARA, RARG, } \\
\text { HDAC4 and KAT2B; IL6R, } \\
\text { IL6ST and ADAM17; TNFR } \\
\text { SF11A; MGAT2 and MGAT3; } \\
\text { PLCG1; CXCL3. } \\
\text { - Difference identified } \\
\text { between rapid ALS and } \\
\text { slow ALS or controls. No } \\
\text { diff between slow ALS and } \\
\text { controls. }\end{array}$ & $\begin{array}{l}\text { Mizwicki et al., } \\
2012 \text { [60] }\end{array}$ \\
\hline $\begin{array}{l}\text { monocyte and } \\
\text { lymphocyte } \\
\text { populations and } \\
\text { activation }\end{array}$ & $\begin{array}{l}\text { Surface expression, } \\
\text { measured by flow cytometry } \\
\text { from monocytes isolated } \\
\text { from whole blood }\end{array}$ & 4-93 months (range) & $\begin{array}{l}n=38 \text { sALS } \\
n=28 \text { controls }\end{array}$ & $\begin{array}{l}\text { - increased percentage of } \\
\text { CD4+ cells in ALS } \\
\text { - increased mean CD14-HLD- } \\
\text { DR expression in ALS } \\
\text { - increased percentage of } \\
\text { CD14 and CD16+ cells in } \\
\text { ALS } \\
\text { - increased serum IgG in ALS } \\
\text { - decreased serum IgM in } \\
\text { ALS }\end{array}$ & $\begin{array}{l}\text { Zhang et al., } \\
2005 \text { [61] }\end{array}$ \\
\hline
\end{tabular}

AD Alzheimer's Disease, ALS amyotrophic lateral sclerosis, ALSFRS-R ALS functional rating scale revised, C9-ALS ALS due to the harboring of the C9orf72 hexanucleotide repeat expansion, CC-16 club cell protein 16, CD14 cluster differentiation 14, CD5L cluster differentiation 5 ligand, CMAP compound muscle action potential, CRP c reactive protein, DC dendritic cells, ELISA enzyme-linked immunosorbent assay, FACS Fluorescence-activated cell sorting, FTD frontal temporal dementia, FoxP3 Forkhead Box P3, FVC forced vital capacity, HLA-DR Human Leukocyte Antigen - DR isotype, HPLC High Performance Liquid Chromatography, IFN- $\gamma$ interferon gamma, IGF- $g$ Insulin-like growth factor gamma, IgG Immunoglobulin G, IgM Immunoglobulin M, IL interleukin, IL-1RA interleukin 1 receptor agonist, IL-18BP interleukin 18 binding protein, IP-10 Interferon gamma-induced protein 10, LBP Lipopolysaccharide binding protein, LPS lipopolysaccharide, MIP-1 $\beta$ Macrophage inflammatory protein 1 beta, MCP-1 Monocyte Chemoattractant Protein 1, MIG monokine induced by gamma interferon, MMP Matrix Metalloproteinases, MSD Meso Scale Discovery (multiplexing), NFkB nuclear factor kappalight-chain-enhancer of activated B cells, NIND non-inflammatory neurological disorder, NK natural killer cells, NLR neutrophil-to-lymphocyte ratio, NO nitric oxide, PBMC peripheral blood mononuclear cell, PD Parkinson's Disease, RANTES Regulated upon Activation, Normal T Cell Expressed and Presumably Secreted, NA ribonucleic acid,

$R T-q P C R$ real time quantitative PCR, sALS sporadic amyotrophic lateral sclerosis, SOD1 super oxide dismutase 1, sTNFR soluble TNF receptor, sTREM2 soluble Triggering Receptor Expressed On Myeloid Cells 2, TNF tumor necrosis factor, TNFR tumor necrosis factor receptor, Tregs T regulatory cells, wrCRP wide-range $\mathrm{c}$ reactive protein

explanations including technology used [63], sample sizes, co-morbidities, (anti-inflammatory) medications, and disease state at biosample donation [64].

Assessing the gene or protein expression of specific cell populations (i.e. not using plasma, serum, or peripheral blood mononuclear cells (PBMCs) in a bulk analysis) provides higher resolution data, and has identified more detailed potential biomarkers. For instance, transcriptomic analyses of monocytes identified an unique inflammation-related gene expression profile, including altered IL-1B, IL-8, FOSB, C-X-C Motif Chemokine
Ligand 1 (CXCL1), and CXCL2 gene expression, which distinguished ALS from control samples [56]. By differentiating blood monocytes into macrophages and conducting transcriptomic analyses on these cells McCauley et al., identified an impaired type I interferon response in the gene expression pathway analysis of ALS cells harboring the C9orf72 repeat expansion [52]. Additionally, in-depth immunophenotyping of 80 ALS and 50 control samples by Gustafson et al., detected an ALS immune cell profile of 32 leukocyte populations, including $\mathrm{T}$ cell phenotypes, and the levels of the activation marker 
Human Leukocyte Antigen DR isotype's (HLA-DR) expression on monocytes [55], which has been confirmed by others [61]. To further assess potential biomarkers in a cell-type specific manner, in vitro assays designed to detect the inflammatory-response post stimulation by lipopolysaccharide (LPS) identified elevated levels of IL8 and CCL-2, but not of TNF, IL-1 $\beta$, IL-6, IL-12p40, IL8, C-C Motif Chemokine Ligand 2 (CCL2) and IL-10, in the conditioned media from ALS dendritic cells [54], a cell type closely related to monocytes. Interestingly, miRNA analysis of neural-enriched extracellular vesicles from plasma identified that miR-146a-5p, also associated to monocyte inflammatory response [49], is increased in ALS [50]. Alternative assays are used by stimulating cells with SOD1 proteins $[57,60]$ or staphylococcal enterotoxin B (SEB) [58] to increase the detectable levels of cytokines, often with a low number of samples included per study, and have not (yet) identified a biomarker.

Although beyond the scope of this review, the reoccurring indication of (activated) monocyte biology as a diagnostic biomarker in ALS begs the question how this cell type may contribute to ALS disease pathophysiology. One such direction may be the increased production of chitinases by monocyte-derived macrophages [65], and/ or by the secretion of cytotoxic cytokines (reviewed in [18]). More research is needed to further our understanding of the contribution of monocyte biology to ALS.

Although some of these biomarkers, or biomarker profiles, distinguish ALS from controls, more research is needed to assess their usefulness to ALS, including their sensitivity, specificity, and robustness to assist in the diagnosis of ALS as many cytokines are also elevated or decreased in other indications. In view of the promising results from cell-type specific analyses, future work could include cell-type specific analyses of circulating or in vitro-invoked inflammatory responses.

\section{Prognostic biomarkers}

In clinical trials, an FDA accepted endpoint of an effective drug for ALS is the slowing of disease-related decline, stabilization, improvement of function in daily activities as measured, for example, by the ALS Functional Rating Scale-Revised (ALSFRS-R) or a similar scale [66]. With the progressively increased inflammation and the progressive decline in ALSFRS-R during disease progression, blood-based markers of inflammation may be exceptionally suitable as prognostic biomarkers. These would predict the rate of decline in a patient, and potentially distinguish between disease sub groups (slow and rapid progressors) and adjust clinical trial eligibility criteria to minimize inter-subject variability. Disease duration is often defined as the number of months post disease onset or diagnosis and survival [30,
67]. As there is significant heterogeneity in the rate of ALS disease progression [68], 'disease duration' may not reflect changes in motor function or independence in daily living as well as the ALSFRS-R, or other quantifiable scales or measurements.

During disease progression, electromyographical measures are altered, including a reduction in the compound motor action potential (CMAP) of the phrenic nerve, as well as a reduction in respiratory measures such as Forced Vital Capacity (FVC). These measurements were both not correlated to CC-16 expression [37], but had a weak inverse correlation with plasma IL-6 expression [33]. The broad and responsive inflammation marker CRP is reported to have a weak correlation with ALS disease duration $[26,28,67,69]$, as well as CD5L, TNF, IFN $\gamma$, and nitric oxide (NO) $[30,45]$. Strikingly, studies assessing pro- and/or anti-inflammatory cytokines (IP10, MCP-1, MIG, RANTES, CC-16 IL-2, IL-4, IL-6, IL-8,

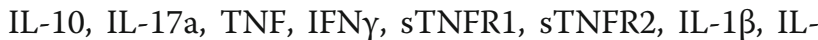
18, IL-33, IL-37, IL-1Ra, sIL-1R2, IL-18BP, sIL-1R4) in the blood of ALS patients (Table 2) were unable to detect a correlation with ALSFRS-R scores of patients that they assessed at the time of biosample donation [27, 33, $34,37,40,70]$. In addition, Devos et al. assessed the levels of IL- 6 in the plasma of 109 ALS patients at the beginning of a clinical trial (NCT00868166) with ALSF RS-R measurements up to 18 months. Although the authors identified a predictive correlation with noninflammation blood-based markers with ALSFRS-R rate of decline (NfL, ferritin, 4-HNE, 8-OHdG), IL-6 levels at baseline were not predictive [70]. Interestingly, a recent study with 79 ALS patient samples, detected a correlation between IL-6 and the ALSFRS-R [29]. These studies indicate that a bulk measurement of a cytokine in plasma or serum may not provide sufficient resolution as a prognostic biomarker, similar to discussed for diagnostic biomarkers. In support of this idea, increasing the resolution of measurement by assessing the expression levels of cytokines, perhaps in combination, on specific blood-based immune cell populations provides potential. As an example of this approach, during the clinical trial assessing the safety of NP001 (regulator of macrophage and monocyte activation) in ALS (NCT01091142), the expression levels of the monocyte activators CD16 and HLA-DR on the surface of monocytes were measured throughout the clinical trial. Although these measurements were not correlated with the score of the ALSFRS-R on the day of biosample donation, they were correlated with ALSFRS-R rate of decline. Moreover, the combination of both markers simultaneously correlated with the ALSFRS-R rate of decline more strongly [72]; a higher the level of activation correlated with a more rapid ALS disease progression [61, 72]. 
Table 2 Blood-based prognostic biomarkers of inflammation in ALS

\begin{tabular}{|c|c|c|c|c|c|}
\hline $\begin{array}{l}\text { Measured } \\
\text { biomarker }\end{array}$ & $\begin{array}{l}\text { Method of } \\
\text { detection }\end{array}$ & $\begin{array}{l}\text { Mean disease } \\
\text { duration at sample } \\
\text { donation }\end{array}$ & Number of samples & Potential Prognostic Value & $\begin{array}{l}\text { Study Reference } \\
\text { Clinical Trial ID }\end{array}$ \\
\hline
\end{tabular}

\section{Blood-derived markers}

\section{$\mathrm{IL}-2, \mathrm{IL}-6, \mathrm{IL}-10$, \\ IFN- $\gamma$, and TNF \\ CD14, LBP and \\ Plasma, BioPlex \\ Serum; ELISAs} CRP

IL-1b, IL-6, IL-10,

IL-12, TNF, IFNg,

IL $17 \mathrm{a}$, and IL-23

CRP

CRP

wide-range C-

reactive protein

(wrCRP)

concentrations

IL-6
IL-6
IP-10, MCP-1,
MIG, RANTES,
IL-2, IL-4, IL-6, IL-
8, IL-10, IL-17a,
TNF, IGF-g,
sTNFR1, STNFR2

Serum; standard laboratory tests laboratory tests

Plasma; Human assay.

$\begin{array}{ll}\begin{array}{l}21.37 \text { months } \\ \text { (median) }\end{array} & n=79 \text { ALS } \\ \text { Not reported } & n=68 \text { ALS (1st cohort) } \\ & n=100 \text { ALS (2nd cohort) }\end{array}$

2.48 years

$n=73 \mathrm{ALS}$

739.9 months

(median)

$n=37 \mathrm{ALS}$

Retrospective study of newly diagnosed ALS patients with up to 5 years of followup (average 2.36 years).

Serum; standard

From whole blood

Not reported Magnetic Luminex Screening Assay

Plasma; Bio-Plex Pro Human Chemokine

Plasma; cytometric 3 years bead array and ELISA

Collection at $1,6,12, \quad n=109$ ALS participants and 18 months into measured over 4 time points the clinical trial

25.7 months time point (6-12 months later)

IL-6 correlated with ALS-FRS-R Tortelli et al., and Manual Muscle Testing. 2020 [29]

- soluble CD14 correlated to burden of disease and progression rate (both cohorts)

- LBP correlated to burden of disease and progression rate (2nd cohort)

- CRP correlated to burden of disease and progression rate (2nd cohort)

- IL-1b was increased in fast progressive ALS

- IL-6 correlated with disease duration (weak correlation)

- IL-1b correlated with the

ALSFRS-R slope

- CD5L was correlated with disease duration and survival (not with ALS-FRS).

- Ficolin-3 was not correlated to disease parameters.

$n=82 \mathrm{ALS}$

$\mathrm{n}=68 \mathrm{ALS}$

$n=24 \mathrm{ALS}$ at the second

$n=399 \operatorname{ALS}(n=122$ very fast progressors, $n=88$, medium progression, $n=189$ slow progression

$n=384$ ALS study)

$n=80 \mathrm{ALS}(n=41 \mathrm{ALS}$ at follow-up 3-6 $\mathrm{m}$ after initial donation; $n=22$ ALS patients at the third donation, and at least 3 months after the second)

Patients with a higher CRP (log-transformed) at baseline had a higher risk of mortality.

- Patients with a higher CRP (log-transformed) than at baseline had a higher risk of mortality.

- CRP (log-transformed) increases in the last few months prior to death in the medium and fast progressing patients)

Increased serum CRP is correlated with an increased rate of functional decline.

- Correlation between the ALSFRS-R and the wrCRP concentration at the first examination.

No correlation with ALS-FRS-R Devos et al., 2019

Reduction in phrenic nerve CMAP amplitude and FVC was correlated with increased IL-6 levels

No correlation with ALS-FRS-R Prado et al., 2018 for any tested markers.

[34] [70] NCT: 00868166

Beers et al., 2020

[26]

Jin et al., 2020

[27]

Mohanty et al., 2020 [30]

Sun et al. 2020

Lunetta et al,

2017 [69]

(NCT01281631)

Keizman et al., 2008 [28]

Pronto-Laborinho et al., 2019 [33] 
Table 2 Blood-based prognostic biomarkers of inflammation in ALS (Continued)

\begin{tabular}{|c|c|c|c|c|c|}
\hline $\begin{array}{l}\text { Measured } \\
\text { biomarker }\end{array}$ & $\begin{array}{l}\text { Method of } \\
\text { detection }\end{array}$ & $\begin{array}{l}\text { Mean disease } \\
\text { duration at sample } \\
\text { donation }\end{array}$ & Number of samples & Potential Prognostic Value & $\begin{array}{l}\text { Study Reference } \\
\text { Clinical Trial ID }\end{array}$ \\
\hline CC-16 & Plasma; ELISA & 27 months & $\mathrm{n}=81 \mathrm{ALS}$ & $\begin{array}{l}\text { No correlation with age, } \\
\text { onset region, disease } \\
\text { duration, functional status, } \\
\text { FVC, and PhrenAmpl. }\end{array}$ & $\begin{array}{l}\text { Pronto-Laborinho } \\
\text { et al., } 2017 \text { [37] }\end{array}$ \\
\hline $\begin{array}{l}\text { IL-1ß, IL-18, IL- } \\
33, \text { IL-37, IL-1Ra, } \\
\text { sIL-1R2, IL-18BP, } \\
\text { sIL-1R4 }\end{array}$ & $\begin{array}{l}\text { Serum; individual } \\
\text { ELISAs }\end{array}$ & 11.32 months & $\mathrm{n}=144$ sporadic ALS & $\begin{array}{l}\text { No correlations with the ALS- } \\
\text { FRS-R were detected. }\end{array}$ & $\begin{array}{l}\text { Italiani et al., } \\
2014[40]\end{array}$ \\
\hline $\begin{array}{l}\text { TGF-b, IL-6, TNF, } \\
\text { IL-17A }\end{array}$ & $\begin{array}{l}\text { Serum; individual } \\
\text { ELISAs }\end{array}$ & From 3 to 96 months & $n=21 \mathrm{ALS}$ & $\begin{array}{l}\text { No correlation between the } 4 \\
\text { cytokines and months after } \\
\text { diagnosis. }\end{array}$ & $\begin{array}{l}\text { Liu et al., } 2012 \\
\text { [71] }\end{array}$ \\
\hline $\begin{array}{l}\text { TNF, IFN- } \gamma \text {, and } \\
\text { NO }\end{array}$ & $\begin{array}{l}\text { Serum; individual } \\
\text { ELISAs and NO by } \\
\text { determining nitrite } \\
\text { and nitrate levels }\end{array}$ & 12 months & $\mathrm{n}=22 \mathrm{ALS}$ & $\begin{array}{l}\text { Correlation between TNF-a, } \\
\text { IFN- } \gamma \text {, and NO levels and dis- } \\
\text { ease duration }\end{array}$ & $\begin{array}{l}\text { Babu et al., } 2008 \\
\text { [45] }\end{array}$ \\
\hline RANTES & $\begin{array}{l}\text { Serum; individual } \\
\text { ELISA }\end{array}$ & Not reported & $n=20 \mathrm{ALS}$ & $\begin{array}{l}\text { No correlation with serum } \\
\text { RANTES and disease duration. }\end{array}$ & $\begin{array}{l}\text { Rentzos et al., } \\
2008 \text { [46] }\end{array}$ \\
\hline $\begin{array}{l}\text { TGF-b, IL-6, TNF, } \\
\text { IL-17A }\end{array}$ & $\begin{array}{l}\text { Serum; individual } \\
\text { ELISAs }\end{array}$ & $\begin{array}{l}\text { From } 3 \text { to } 96 \text { months } \\
\text { (range) }\end{array}$ & $n=21 \mathrm{ALS}$ & $\begin{array}{l}\text { TGF- } \beta \text { and IL- } 6 \text { were in- } \\
\text { creased in some patients } \\
\text { since the onset of symptoms, } \\
\text { whereas IL-17A and TNF- } \alpha \\
\text { levels were increased only in } \\
\text { the mid-course of the disease } \\
\text { (no statistics reported) }\end{array}$ & $\begin{array}{l}\text { Liu et al., } 2012 \\
\text { [71] }\end{array}$ \\
\hline \multicolumn{6}{|c|}{ Blood-derived cells, in vitro assays } \\
\hline $\begin{array}{l}\text { Monocyte } \\
\text { subpopulations }\end{array}$ & $\begin{array}{l}\text { Monocyte isolation kit } \\
\text { from peripheral } \\
\text { blood, and flow } \\
\text { cytometry }\end{array}$ & Not reported & $\begin{array}{l}n=68 \text { ALS (1st cohort) } \\
n=100 \text { ALS (2nd cohort) }\end{array}$ & $\begin{array}{l}\text { - CD14-/low/CD16+ } \\
\text { monocytes negatively } \\
\text { correlated with disease } \\
\text { burden and rate of } \\
\text { progression in ALS }\end{array}$ & $\begin{array}{l}\text { Beers et al., } 2020 \\
{[26]}\end{array}$ \\
\hline $\begin{array}{l}\text { Subpopulations } \\
\text { of T cells, B cells, } \\
\text { natural killer } \\
\text { cells, and } \\
\text { antigen } \\
\text { presenting cells }\end{array}$ & $\begin{array}{l}\text { Peripheral blood and } \\
\text { FACS }\end{array}$ & 2.48 years & $\mathrm{n}=73 \mathrm{ALS}$ & $\begin{array}{l}\text { - increased NK cells in slow vs } \\
\text { fast progressive ALS } \\
\text { - no difference between slow } \\
\text { and fast progressive ALS for } \\
\text { any other cell population } \\
\text { - Th1/Th2 ratio correlated } \\
\text { with the ALSFRS-R slope } \\
\text { - Th17/Treg ratio correlated } \\
\text { with the ALSFRS-R }\end{array}$ & $\begin{array}{l}\text { Jin et al., } 2020 \\
{[27]}\end{array}$ \\
\hline $\begin{array}{l}\text { Concentrations } \\
\text { of TNF, IL-1 } \beta, \text { IL- } \\
6, I L-12 p 40, I L-8 \text {, } \\
\text { CCL2 and } \\
\text { IL-10 in DC } \\
\text { supernatants }\end{array}$ & $\begin{array}{l}\text { Circulating myeloid } \\
\text { dendritic (CD1chigh) } \\
\text { cells stimulated with } \\
\text { LPS. }\end{array}$ & Not calculated & $\mathrm{n}=52 \mathrm{ALS}$ & $\begin{array}{l}\text { Inverse correlation between } \\
\text { the time from onset to } \\
\text { diagnosis and the levels of IL- } \\
6 \text { secretion induced by LPS. }\end{array}$ & $\begin{array}{l}\text { Rusconi et al., } \\
2017 \text { [54] }\end{array}$ \\
\hline $\begin{array}{l}116 \text { leukocyte } \\
\text { populations and } \\
\text { phenotypes } \\
\text { from } \\
\text { lymphocytes, } \\
\text { monocytes, and } \\
\text { granulocytes }\end{array}$ & $\begin{array}{l}\text { Peripheral blood } \\
\text { immunophenotyping } \\
\text { by flow cytometry }\end{array}$ & 21.6 months & $\mathrm{n}=80 \mathrm{ALS}$ & $\begin{array}{l}\text { Different immuno-phenotypic } \\
\text { markers associate with clinical } \\
\text { parameters, incl. Survival, in } \\
\text { the } 2 \text { ALS immune profiles. }\end{array}$ & $\begin{array}{l}\text { Gustafson et al., } \\
2017 \text { [55] }\end{array}$ \\
\hline $\begin{array}{l}\text { Transcriptomic } \\
\text { analysis }\end{array}$ & $\begin{array}{l}\text { RNA sequencing of } \\
\text { blood monocytes }\end{array}$ & Not reported & $\mathrm{n}=43 \mathrm{ALS}$ & $\begin{array}{l}\text { ALS monocytes from rapidly } \\
\text { progressing patients had } \\
\text { more proinflammatory DEGs } \\
\text { than monocytes from slowly } \\
\text { progressing patients. }\end{array}$ & $\begin{array}{l}\text { Zhao et al., } 2017 \\
\text { [56] }\end{array}$ \\
\hline $\begin{array}{l}\text { Transcriptomic } \\
\text { and methylation } \\
\text { analysis }\end{array}$ & $\begin{array}{l}\text { RNAseq and RRBS on } \\
\text { PBMCs }\end{array}$ & Not reported & 1 discordant twin pair & $\begin{array}{l}\text { - Higher abundance of CD14 } \\
\text { macrophages in ALS over } \\
\text { time }\end{array}$ & $\begin{array}{l}\text { Lam et al., } 201 \\
6[57]\end{array}$ \\
\hline
\end{tabular}


Table 2 Blood-based prognostic biomarkers of inflammation in ALS (Continued)

\begin{tabular}{|c|c|c|c|c|c|}
\hline $\begin{array}{l}\text { Measured } \\
\text { biomarker }\end{array}$ & $\begin{array}{l}\text { Method of } \\
\text { detection }\end{array}$ & $\begin{array}{l}\text { Mean disease } \\
\text { duration at sample } \\
\text { donation }\end{array}$ & Number of samples & Potential Prognostic Value & $\begin{array}{l}\text { Study Reference } \\
\text { Clinical Trial ID }\end{array}$ \\
\hline & & & & $\begin{array}{l}\text { - Lower abundance of T cells } \\
\text { in ALS over time }\end{array}$ & \\
\hline $\begin{array}{l}\text { CD16 and HLA- } \\
\text { DR }\end{array}$ & $\begin{array}{l}\text { Surface expression, } \\
\text { measured by flow } \\
\text { cytometry from } \\
\text { monocytes isolated } \\
\text { from whole blood }\end{array}$ & 24.1 months & $\mathrm{n}=24 \mathrm{ALS}$ & $\begin{array}{l}\text { - CD14 correlated with ALS- } \\
\text { FRS-R rate of change } \\
\text { - CD14/HLA-DR correlated } \\
\text { with ALS-FRS-R rate of } \\
\text { change }\end{array}$ & $\begin{array}{l}\text { Miller et al., } 2014 \\
\text { [72] } \\
\text { NCT01091142, } \\
\text { Ph1 NP001 in } \\
\text { ALS }\end{array}$ \\
\hline $\begin{array}{l}\text { monocyte and } \\
\text { lymphocyte } \\
\text { populations and } \\
\text { activation }\end{array}$ & $\begin{array}{l}\text { Surface expression, } \\
\text { measured by flow } \\
\text { cytometry from } \\
\text { monocytes isolated } \\
\text { from whole blood }\end{array}$ & 4-93 months (range) & $\mathrm{n}=38 \mathrm{sALS}$ & $\begin{array}{l}\text { - HLA-DR expression on } \\
\text { CD14+ cells correlated with } \\
\text { ALSFRS-R }\end{array}$ & $\begin{array}{l}\text { Zhang et al., } \\
2005 \text { [61] }\end{array}$ \\
\hline $\begin{array}{l}\text { Leukocyte } \\
\text { number and } \\
\text { expression of } \\
\text { FoxP3, TGF-b, IL- } \\
\text { 4, Gata-3, IL-10, } \\
\text { Tbx21, IFN- } \gamma\end{array}$ & $\begin{array}{l}\text { T-lymphocytes } \\
\text { assessed by flow } \\
\text { cytometry, and gene } \\
\text { expression by RT- } \\
\text { qPCR }\end{array}$ & Not reported & $\begin{array}{l}n=54 \mathrm{ALS} \\
n=102 \mathrm{ALS} \text { (replication) }\end{array}$ & $\begin{array}{l}\text { - Number of Tregs and their } \\
\text { FoxP3 protein expressions } \\
\text { were reduced in rapidly } \\
\text { progressing ALS patients } \\
\text { and inversely correlated } \\
\text { with progression rates } \\
\text { (AALS). } \\
\text { - The mRNA levels of FoxP3, } \\
\text { TGF-b, IL4 and Gata3, were } \\
\text { reduced in rapidly progres- } \\
\text { sing patients and inversely } \\
\text { correlated with progression } \\
\text { rates. } \\
\text { - FoxP3 and Gata3 were } \\
\text { indicators of progression } \\
\text { rates. } \\
\text { - No differences in IL10, } \\
\text { Tbx21, or IFN- } y \text { expression } \\
\text { were found between slow } \\
\text { and rapidly progressing } \\
\text { patients. }\end{array}$ & $\begin{array}{l}\text { Henkel et al., } \\
2012 \text { [73] }\end{array}$ \\
\hline
\end{tabular}

ALS amyotrophic lateral sclerosis, ALSFRS-R ALS functional rating scale revised, CC-16 club cell protein 16, CCL2 C-C Motif Chemokine Ligand 2, CD5L cluster differentiation 5 ligand, CD14 cluster differentiation 14, CMAP compound muscle action potential, CRP c reactive protein, DC dendritic cells, ELISA enzyme-linked immunosorbent assay, FACS Fluorescence-activated cell sorting, FVC forced vital capacity, FoxP3 Forkhead Box P3, HLA-DR Human Leukocyte Antigen - DR isotype, IFN-y interferon gamma, IGF- $g$ Insulin-like growth factor gamma, IL interleukin, IL-18BP interleukin 18 binding protein, IL-1RA interleukin 1 receptor agonist, IP-10 Interferon gamma-induced protein 10, LBP Lipopolysaccharide binding protein, LPS lipopolysaccharide, MIG monokine induced by gamma interferon, MCP-1 Monocyte Chemoattractant Protein 1, NK natural killer cells, NO nitric oxide, PBMC peripheral blood mononuclear cell, RANTES Regulated upon Activation, Normal T Cell Expressed and Presumably Secreted, $R N A$ ribonucleic acid, RRBS Reduced representation bisulfite sequencing, $R T-q P C R$ real time quantitative PCR, sIL- $1 R$ soluble IL receptor, sTNFR soluble TNF receptor, Tbx21 T-Box Transcription Factor 21, TGF- $\beta 1$ tumor growth factor beta 1, TNF tumor necrosis factor, Tregs T regulatory cells, wrCRP wide-range $\mathrm{c}$ reactive protein

In addition, in-depth immunophenotyping of 116 leukocyte populations from blood-derived immune cells identified a monocyte immune profile, as well as an Treg immune profile, in a subpopulation of ALS patients correlated to the ALSFRS-R and survival [55]. This subpopulation accounts for $\sim 39 \%$ of the tested cohort, were generally younger ( 54.8 vs. 60.5 years old), were more likely familial ALS (26.1\% vs $2.8 \%$ ), and survived longer than patients without this specific immune profile (344 vs. 184 weeks) [55], indicating that this specific inflammatory profile may be protective. Moreover, specifically assessing the transcriptomic profile of blood-derived monocytes additionally also identified alternative gene expression in monocytes between patients with a rapid and slow disease progression [56].
The value of cell population specific studies is further illustrated by the study from Henkel et al., in which they define a slow and rapid disease progression on basis on the Appel ALS score (AALS) [74]. The abundance of Tregs and the their FoxP3 protein expression was lower in rapidly progressing ALS patients, and was inversely correlated with disease progression rates determined by the AALS [73]. In addition, the gene expression levels of FoxP3, TGF-b, IL-4 and Gata3 from leukocytes were also decreased in rapidly progressing patients, and also inversely correlated to progression rate [73], whereas when measured in plasma the levels of TGF-b [71] and IL-4 [34] were not correlated to disease progression.

The subpopulations described by Jin et al., Beers et al., Henkel et al., Zhao et al., and Gustafson et al., imply that 
there are discernable subtypes of progression in ALS that are associated with inflammatory responses detectable in blood. Monitoring these responses could be used in population stratification for clinical trials, or as biomarkers that predict responders. The population-specific characteristics between these studies overlap in the identification of monocytes, T-regs and their responses as possible distinguishers of these subpopulations [26, 27, 55, 56, 73].

The future of prognostic biomarkers in ALS may include their use to predict disease progression rate, and thus clinical trial eligibility. Strides have been made to use a disease progression predicting algorithm to minimize variation and expand potential clinical trial eligibility $[75,76]$, as well as to perform post-hoc analyses to assess drug efficacy per participant, although these have not yet incorporated biological biomarkers. Future studies may determine whether inclusion of blood-based biomarkers (of inflammation) may increase the accuracy of the algorithm, e.g. for each of the subpopulations identified by immune profiles by Gustafson et al. [55]. In addition, with novel research, prognostic biomarkers may be applied to predict not only the disease progression after disease onset, but perhaps also predict phenoconversion from a pre-symptomatic to a symptomatic disease stage in high-risk individuals (e.g. those harboring a known ALS mutation) [77, 78]. A longitudinal study with healthy aging, mild cognitive impairment, and Alzheimer's Disease participants over 5 years identified approximate time windows prior to phenoconversion and to the next disease symptom on the basis of biomarker changes detected many years prior [79]. In individuals at risk for ALS, NfL is increased in plasma and CSF $\sim 12$ months prior to symptom onset [80]. The future identification of additional prognostic biomarkers for phenoconversion in ALS may allow for an understanding of possible prevention intervention windows [77].

\section{Pharmacodynamic biomarkers}

Despite the prediction that neuroinflammation contributes significantly to ALS pathophysiology [19], antiinflammatory therapeutic strategies have failed in clinical trials in ALS [1]. The inclusion of readouts to confirm target engagement (pharmacodynamic biomarkers) in clinical trial design assist in confirming whether the therapeutic exerted the expected effect per participant throughout the treatment paradigm informing also target validity, and is highly recommended [81, 82]. In fact, the hypothetic inclusion of pharmacodynamic biomarkers in previous clinical trials may have aided in the understanding of the drugs or targets in ALS, and perhaps would have minimized clinical trials on the same target due to this increased knowledge. Although many therapeutics aim to target inflammation of the CNS, peripheral readouts may be established as a proxy readout. An example is monocyte activation as measurement of NP001 target engagement [72], or cytokine profiling in CSF and blood [83, 84]. Interestingly, a Phase 2 trial of tocilizumab (a humanized monoclonal antibody against the IL-6 receptor) in ALS (NCT02469896) assessed both mRNA profiling of PBMCs and CRP expression in blood and CSF, and although the transcriptomic readout was inadequate as a pharmacodynamic (or predictive) biomarker [84], the CRP levels were significantly altered by the treatment and may function as a pharmacodynamic biomarker.

Table 3 includes the biomarkers used in Phase 3 clinical trials targeting inflammation in ALS, as published or listed on clinicaltrials.gov supplemented with any peer-reviewed published information. Even in the case of targeting (neuro) inflammation with a medical product in ALS, few clinical trial designs include pharmacodynamic biomarkers (Table 3), although these may have been included at an earlier clinical stage. Perhaps due to the laborintensive nature of in vitro assays, and the needed standardization or coordination between clinical sites, these paradigms have not (yet) been utilized as pharmacodynamic biomarkers in ALS during treatment (Table 3).

\section{Predictive biomarkers}

The strong heterogeneity of the ALS clinical phenotypes [85] and the identification of specific immune phenotypes and inflammatory responses that correlate with rate of disease progression $[26,55,73]$, imply that subsets of ALS patients exist and that some may be particularly responsive to a therapeutic target and drug. A priori predictions of the potential responsiveness per patient to a therapeutic strategy could lead to clinical trial inclusion criteria on basis of such a predictive biomarker, and thus an enrichment of potentially responsive participants per clinical trial, as well as support personalized medicine endeavors [82]. For instance in ALS, the Phase 2 clinical trial for NP001, a monocyte and macrophage regulator, identified CRP levels as a predictor of responsiveness [69].

\section{Safety biomarkers}

With the testing of novel medical products there is a need to identify potential safety biomarkers that will predict adverse events prior to the event occurring. An example is the monitoring of liver enzymes during the treatment with a drug that may cause liver damage, or particularly in those participants with a specific genetic polymorphism that affects drug metabolism to predict whether e.g. irreversible liver damage will occur. With the advancement of novel technologies in medical products, and with the genetic component of ALS, new 
Table 3 Phase 3 clinical trials in ALS with a medical product targeting (neuro)inflammation

\begin{tabular}{|c|c|c|c|c|c|}
\hline $\begin{array}{l}\text { Intervention, Sponsor } \\
\text { or Collaborators, } \\
\text { Phase }\end{array}$ & $\begin{array}{l}\text { Target or } \\
\text { Mechanism of } \\
\text { Action and Protocol }\end{array}$ & Outcome Measures & $\begin{array}{l}\text { Pharmacodynamic } \\
\text { Biomarker }\end{array}$ & Study results & $\begin{array}{l}\text { Reference } \\
\text { Clinical Trial } \\
\text { ID }\end{array}$ \\
\hline $\begin{array}{l}\text { Drug: } \\
\text { minocyclineSponsor: } \\
\text { National Institute of } \\
\text { Neurological Disorders } \\
\text { and Stroke (NINDS) } \\
\text { Phase: } 3\end{array}$ & $\begin{array}{l}\text { - anti-inflammatory } \\
\text { - daily dose for } 9 \\
\text { months }\end{array}$ & $\begin{array}{l}\text { - change in function as } \\
\text { detected by the ALSF } \\
\text { RS-R } \\
\text { - changes in manual } \\
\text { muscle testing (MMT), } \\
\text { forced vital capacity } \\
\text { (FVC, percent } \\
\text { predicted), quality of life } \\
\text { (QOL) and survival }\end{array}$ & none listed or described & $\begin{array}{l}\text { - ALSFRS-R score } \\
\text { deterioration was faster } \\
\text { - (non-significant } \\
\text { tendencies towards } \\
\text { faster decline in FVC } \\
\text { and MMT score, and } \\
\text { greater mortality } \\
\text { during the 9-month } \\
\text { treatment phase } \\
\text { - Quality-of-life scores } \\
\text { did not differ between } \\
\text { the treatment groups. } \\
\text { - Non-serious gastro- } \\
\text { intestinal and neuro- } \\
\text { logical adverse events } \\
\text { were more common in } \\
\text { the minocycline group } \\
\text { than in the placebo } \\
\text { group, but these } \\
\text { events were not signifi- } \\
\text { cantly related to the } \\
\text { decline in ALSFRS-R } \\
\text { score. }\end{array}$ & $\begin{array}{l}\text { Gordon et al., } \\
2007 \\
\text { [3]NCT00047723 }\end{array}$ \\
\hline $\begin{array}{l}\text { Drug: Granulocyte } \\
\text { Colony Stimulating } \\
\text { FactorSponsor: Tehran } \\
\text { University of Medical } \\
\text { Sciences } \\
\text { Phase: } 2 / 3\end{array}$ & $\begin{array}{l}\text { - G-CSF administered } \\
\text { per subcutaneous } \\
\text { injection } \\
\text { - } 5 \text { days treatment } \\
\text { with } 3 \text { month } \\
\text { follow-up }\end{array}$ & $\begin{array}{l}\text { - patient's function } \\
\text { - mobilizing bone } \\
\text { marrow stem cells- } \\
\text { amplitude of } \\
\text { compound muscle } \\
\text { action potential in ulnar } \\
\text { and peroneal nerve- } \\
\text { quality of life- muscle } \\
\text { power }\end{array}$ & $\begin{array}{l}\text { mobilizing bone marrow } \\
\text { stem cells: } \\
\text { - cluster of differentiation } \\
34 \text { (CD34) } \\
\text { - white blood cell (WBC) } \\
\text { counting }\end{array}$ & - no significant effect & $\begin{array}{l}\text { Amirzagar et al., } \\
2015 \text { [4] } \\
\text { NCT01825551 }\end{array}$ \\
\hline $\begin{array}{l}\text { Drug: MediCabilis CBD } \\
\text { Oil } \\
\text { Sponsor: Gold Coast }\end{array}$ & $\begin{array}{l}\text { - anti-inflammatory } \\
\text { - treatment for } 6 \\
\text { months }\end{array}$ & $\begin{array}{l}\text { - difference in mean } \\
\text { ALSFRS-R } \\
\text { - difference in mean }\end{array}$ & none listed & $\begin{array}{l}\text { - not available yet } \\
\text { (recruiting) }\end{array}$ & $\begin{array}{l}\text { Urbi et al., } 2019 \\
\text { [5] } \\
\text { NCT03690791 }\end{array}$ \\
\hline
\end{tabular}

\section{Hospital and Health \\ Service, BOD Australia \\ Phase: 3}

Drug: Masitinib (4.5/

3.0)Sponsor: AB Science

Phase: $2 / 3$

\section{- treatment for 6 \\ months}

Forced Vital Capacity (FVC)

- nature and number of adverse events

- difference in mean

Numeric Rating Scale for spasticity

- difference in mean Numeric Rating Scale

for pain total score

- difference in mean

Percentage of Total

Weight Loss score

- difference in mean ALS

Specific Quality of Life-

Revised

- change in ALSFRS-R

- change of Forced Vital

Capacity (FVC)

- progression Free

Survival

- overall Survival
Drug: Masitinib (6.0/4.5) - microglia \& mast - ALSFRS-R

Sponsor: AB Science cells through c-kit - ALSAQ-40
- microglia \& mast

-48 weeks none listed or described
- "Normal progressor" Mora et al., subpopulation received 2020 [6] a benefit from the drug NCT02588677 on the $\triangle A L S F R S-R$ and on the ALSAQ-40, FVC, and time-to-event analysis.
- No differences were detected in the full sample ("Normal and Fast Progressor").

- not available yet (recruiting) 
Table 3 Phase 3 clinical trials in ALS with a medical product targeting (neuro)inflammation (Continued)

\begin{tabular}{|c|c|c|c|c|c|}
\hline $\begin{array}{l}\text { Intervention, Sponsor } \\
\text { or Collaborators, } \\
\text { Phase }\end{array}$ & $\begin{array}{l}\text { Target or } \\
\text { Mechanism of } \\
\text { Action and Protocol }\end{array}$ & Outcome Measures & $\begin{array}{l}\text { Pharmacodynamic } \\
\text { Biomarker }\end{array}$ & Study results & $\begin{array}{l}\text { Reference } \\
\text { Clinical Trial } \\
\text { ID }\end{array}$ \\
\hline Phase: 3 & - 48 weeks & $\begin{array}{l}\text { - progression free survival } \\
\text { - FVC } \\
\text { - HHD }\end{array}$ & & & \\
\hline $\begin{array}{l}\text { Drug: } \\
\text { ZilucoplanSponsor: Ra } \\
\text { Pharmaceuticals } \\
\text { Phase: } 2 / 3\end{array}$ & $\begin{array}{l}\text { - complement C5 } \\
\text { inhibitor } \\
\text { - } 24 \text { weeks }\end{array}$ & $\begin{array}{l}\text { - disease progression } \\
\text { - respiratory function } \\
\text { - muscle strength } \\
\text { - survival }\end{array}$ & none listed & $\begin{array}{l}\text { - not available yet } \\
\text { (recruiting) }\end{array}$ & NCT04436497 \\
\hline $\begin{array}{l}\text { Drug: } \\
\text { VerdiperstatSponsor: } \\
\text { Biohaven } \\
\text { Pharmaceuticals, Inc. } \\
\text { Phase: } 2 / 3\end{array}$ & $\begin{array}{l}\text { - myeloperoxidase } \\
\text { (MPO) enzyme } \\
\text { inhibitor } \\
\text { - } 24 \text { weeks }\end{array}$ & $\begin{array}{l}\text { - disease progression } \\
\text { - respiratory function } \\
\text { - muscle strength } \\
\text { - survival }\end{array}$ & none listed & $\begin{array}{l}\text { - not available yet } \\
\text { (recruiting) }\end{array}$ & NCT04436510 \\
\hline $\begin{array}{l}\text { Drug: MN-166 (Ibudi- } \\
\text { last)Sponsor: } \\
\text { MediciNova } \\
\text { Phase: } 2 / 3\end{array}$ & $\begin{array}{l}\text { - phosphodiesterase } \\
\text { inhibitor (PDE4) } \\
\text { - } 52 \text { weeks of } \\
\text { treatment }\end{array}$ & $\begin{array}{l}\text { - change from baseline in } \\
\text { ALSFRS-R score at } \\
\text { Month } 12 \\
\text { - survival time } \\
\text { - mean change of muscle } \\
\text { strength measured by } \\
\text { hand-held } \\
\text { dynamometry } \\
\text { - mean change from } \\
\text { baseline on quality of } \\
\text { life by ALSAQ-5 } \\
\text { - mean change from } \\
\text { baseline of functional } \\
\text { activity by ALSFRS-R } \\
\text { - responders, measured } \\
\text { in percent of subjects } \\
\text { overall, whose ALSFRS-R } \\
\text { total score was stable or } \\
\text { improved } \\
\text { - time to survival } \\
\text { - number of Participants } \\
\text { with Treatment-Related } \\
\text { Adverse Events } \\
\text { - changes from Baseline } \\
\text { in Laboratory Values }\end{array}$ & $\begin{array}{l}\text { not specified (laboratory } \\
\text { values) }\end{array}$ & $\begin{array}{l}\text { - not available yet } \\
\text { (recruiting) }\end{array}$ & NCT04057898 \\
\hline $\begin{array}{l}\text { Biological: } \\
\text { LenzumestrocelSponsor: } \\
\text { Corestem, Inc. } \\
\text { Phase: } 3\end{array}$ & $\begin{array}{l}\text { - intrathecal } \\
\text { autologous bone } \\
\text { marrow-derived } \\
\text { mesenchymal stem } \\
\text { cells injections to } \\
\text { minimize pro- } \\
\text { inflammatory } \\
\text { cytokines } \\
\text { - Study drug } \\
\text { injections twice in a } \\
\text { 26-day interval } \\
\text { followed by re- } \\
\text { peated three times } \\
\text { study drug injec- } \\
\text { tions every three } \\
\text { months. }\end{array}$ & $\begin{array}{l}\text { - joint rank scores (CAFS, } \\
\text { Combined Assessment } \\
\text { of Functional and } \\
\text { Survival) } \\
\text { - ALSFRS-R score } \\
\text { - time to event } \\
\text { - Slow Vital Capacity } \\
\text { (SVC) }\end{array}$ & $\begin{array}{l}\text { Exploratory investigation } \\
\text { of biological markers in } \\
\text { plasma, blood and CSF. } \\
\text { Comparison of change } \\
\text { before and after } \\
\text { treatment. Measurement } \\
\text { cytokines: TGF- } \beta 1 \text {, IL-10, } \\
\text { IL-6, TNF, MCP- } 1 \text {, IL-8, IL- } \\
\text { 1RA, MIP-1 } \beta \text {, RANTES and } \\
\text { IP-10 etc. }\end{array}$ & $\begin{array}{l}\text { - not available yet } \\
\text { (recruiting) }\end{array}$ & NCT04745299 \\
\hline $\begin{array}{l}\text { Biological: } \\
\text { RavulizumabSponsor: } \\
\text { Alexion Pharmaceuticals } \\
\text { Phase: } 3\end{array}$ & $\begin{array}{l}\text { - complement } \\
\text { inhibitor } \\
\text { - } 50 \text { weeks }\end{array}$ & $\begin{array}{l}\text { - change From Baseline } \\
\text { ALSFRS-R Total Score } \\
\text { - time To Ventilator } \\
\text { Assistance-free Survival } \\
\text { - change From Baseline } \\
\text { In Slow Vital Capacity } \\
\text { - incidence Of Treatment- } \\
\text { emergent Adverse } \\
\text { Events (TEAEs), } \\
\text { Treatment-emergent }\end{array}$ & none listed & $\begin{array}{l}\text { - not available yet } \\
\text { (recruiting) }\end{array}$ & NCT04248465 \\
\hline
\end{tabular}


Table 3 Phase 3 clinical trials in ALS with a medical product targeting (neuro)inflammation (Continued)

\begin{tabular}{|c|c|c|c|c|c|}
\hline $\begin{array}{l}\text { Intervention, Sponsor } \\
\text { or Collaborators, } \\
\text { Phase }\end{array}$ & $\begin{array}{l}\text { Target or } \\
\text { Mechanism of } \\
\text { Action and Protocol }\end{array}$ & Outcome Measures & $\begin{array}{l}\text { Pharmacodynamic } \\
\text { Biomarker }\end{array}$ & Study results & $\begin{array}{l}\text { Reference } \\
\text { Clinical Trial } \\
\text { ID }\end{array}$ \\
\hline & & $\begin{array}{l}\text { Serious Adverse Events, } \\
\text { And TEAEs Leading To } \\
\text { Study Drug } \\
\text { Discontinuation } \\
\text { - change From Baseline } \\
\text { In Muscle Strength As } \\
\text { Assessed By Handheld } \\
\text { Dynamometry } \\
\text { - change From Baseline } \\
\text { In Serum Neurofilament } \\
\text { Light Chain }\end{array}$ & & & \\
\hline
\end{tabular}

ALSAQ-5 five item ALS assessment questionnaire, ALSAQ-40 forty item ALS assessment questionnaire, ALSFRS-R ALS functional rating scale revised, CAFS Combined Assessment of Functional and Survival, CD34 cluster of differentiation 34, c-kit tyrosine-protein kinase Kit, CSF cerebral spinal fluid, FVC forced vital capacity, HHD hand-held dynamometry, IL interleukin, IL-1RA interleukin 1 receptor agonist, IP-10 Interferon gamma-induced protein 10, MCP-1 Monocyte Chemoattractant Protein 1, MIP-1 $\beta$ Macrophage inflammatory protein 1 beta, MMT manual muscle testing, MPO myeloperoxidase, NINDS National Institute of Neurological Disorders and Stroke, PDE4 phosphodiesterase inhibitor 4, QOL quality of life, RANTES Regulated upon Activation, Normal T Cell Expressed and Presumably Secreted, SVC Slow Vital Capacity, TEAEs Treatment-emergent Adverse Events, TGF- $\beta 1$ tumor growth factor beta 1, TNF tumor necrosis factor, WBC white blood cell

technologies are developed with new (unknown) risk profiles, in particular biologics [86], including monoclonal antibodies, antisense oligonucleotides (ASOs), AAVdelivered gene therapies, and cell therapies. The safety risks can include excessive inflammation, immunogenicity, cytokine storms, and ultimately sepsis. Monoclonal antibody treatment, e.g. to address (neuro) inflammation in ALS, can give rise to cytokine release syndrome, which is an exaggerated systemic immune response involving the potential release of more than 150 inflammatory mediators [87]. This syndrome can be identified by monitoring cytokine levels in the blood post treatment, and can be treated promptly when detected [87]. ASO treatment has found increased application in clinical development in ALS; initially by targeting of the SOD1 gene for ALS patients harboring an ALS-causing mutation in this gene in clinical trials [88], and with the additional development of ASO treatment for C9orf72 repeat expansion carriers (NCT03626012, NCT04288856) as well as the targeting of the CAG repeat expansion of the genetic disease modifier ATXN2 (NCT04494256). Please note that these potential ASO treatments are still in clinical development and have not (yet) received marketing approval. These potential treatments involve the intrathecal injection of targeting ASOs, and provide the risk of infection [89], including meningitis, and of the above-described cytokine release syndrome, which has also been observed with ASO treatment [90]. Both of these safety risks can be detected early in blood for subsequent treatment. An alternative delivery of gene-based therapies is the use of viral vectors, e.g. adeno-associated virus (AAV), in preclinical development and as marketed medical products (e.g. Zolgensma for spinal muscular atrophy). Immunogenicity to the viral vector provides a risk to the efficacy of the potential therapy as well as a risk to adverse effects and complications from the treatment. For CNS bioavailable gene therapies this can include the neuroinflammatory response [91]. Treatment of ALS with cells that are intended to replace non-neuronal cells and/or support motor neuron health by controlling the milieu with trophic or antiinflammatory factors have not (yet) demonstrated efficacy for ALS patients, but are in clinical development [92, 93]. These cell therapies may also harbor severe safety risks including immunogenicity and cytokine storms, which must be monitored and may be predicted with biomarkers. To this end, the use of blood-based inflammation biomarkers may be particularly useful to predict, and thereby potentially prevent, (serious) adverse events in clinical trials and/or in the initial or prolonged use of a marketed product.

\section{Conclusions}

The peripheral inflammatory signature in ALS includes changes in cell population abundance, gene expression changes per cell population, and soluble factors such as cytokines; which elements reach pathologic significance is not at all clear. Therefore, it is not surprising that a single inflammatory marker derived from serum or plasma may not provide the needed sensitivity to distinguish between an ALS disease state, predict ALS disease progression, or assess whether a tested therapy is efficacious. The first potential solution is the inclusion of multiple readouts per sample to determine a combinatorial biomarker's validity, which can be gene expression from the same cell [72], as well as combinations of different assays, including from cellular-based assays. In particular, the monocytic and T-reg pathway may be enriched for useful biomarkers in ALS. Conversely, monocytic and macrophage-based inflammation has been targeted therapeutically by NP001, and was not efficacious on the needed primary endpoints for FDA market approval in ALS $[69,72,94]$. Despite that targeting 
these pathways was not efficacious, these pathways may be enriched for useful biomarkers for future cell-specific and combined assessments, and may indicate disease processes that are more upstream than what was targeted. In particular, an in-depth assessment of monocyte-populations and their cell-specific transcription profiles (as described below), either by single cell sequencing or nuclear sequencing after monocyteenrichment, may be a fruitful strategy for high-resolution biomarker detection. In addition, incorporating this combination approach with patient level clinical phenotype data could identify inflammatory traits and subgroups more responsive to selected therapies [13]. For example, the pattern of inflammation in upper motor neuron predominant disease may differ significantly from patients with lower motor neuron specific disease. This identification of novel associations may help to better classify disease and treatment approaches, allowing, ultimately, for stratification by inflammatory, or some other, biomarker trait.

The advanced technologies over the last decade allow for more detailed, in-depth, and higher resolution analyses, promoting the potential of combinatorial readouts from niche cell populations with e.g. the advances in single cell transcriptomic analyses which provides a large number of data points for all cell types in a sample, also for cells in blood and CSF in disease [95]. Current limitations of single cell sequencing involve the detection of poly-A adenylated gene expression transcripts only, ensuring that for assessing miRNAs or circRNAs per cell population, prior cell-sorting will be needed. miRNA studies on ALS serum, without cell-type specific sorting, also report variable results [96-98], reminiscent of the variation described above regarding cytokine analyses on serum. Cell type specific miRNAs and/or circRNAs may provide novel avenues for biomarker development in (neuro) inflammation [99] and in ALS [100]. These readouts can additionally be assessed in cell type specific in vitro assays, and both unstimulated and stimulated responses should be assessed, as the level of T-reg and monocyte activation is important $[56,61,72]$.

In view of the studies discussed here, a compelling direction is the combination of single cell transcriptomic analyses on whole blood samples, in addition to cellularbased assays of a specific cell population. In addition, the combined biomarkers may gain in sensitivity and specificity when combined with other biomarkers, such as the established $\mathrm{p} 75^{\mathrm{ECD}}$ and/or neurofilament light. Other biomarkers under development include miRNAs, circRNAs, and the content of extracellular vesicles and exosomes from circulating blood cells or from in vitro assays, or other biomarkers such as neuroimaging (e.g. DTI or PET) and/or electrophysiological measurements (e.g. MUNIX) [64].
For the development of diagnostic and prognostic biomarkers in ALS of blood-based circulating factors (most cellular-based assays require fresh samples, as cell quality may be affected by long-term storage conditions [101]), many previously collected samples are available at biobanks and biorepositories. New sample collections e.g. during clinical trials of a potential therapeutic agent are recommended for monitoring, prognostic, pharmacodynamic, and predictive biomarkers, or those requiring fresh samples for cellular-based assays (as conducted in Table 2). During the collection of new samples, also across multiple clinical trial sites, it is essential that the samples are collected and prepared as similarly as possible, especially when intended to assess immune or inflammatory biomarkers. The variability during sample collection and preparation can result in variable levels of immune/inflammatory cell "activation", which can introduce experimental artifacts into both the results and interpretations [102]. Systematic approaches, standard operating protocol adherence and (repeated) training across sites may be of assistance [102, 103]. In addition, large-scaled retrospective studies of electronic medical records (EMRs) (e.g. Sun et al., [67]), and correlating biomarkers or biomarker profiles with diseaseprogression predictions [76], is recommended.

The studies assessed in this review highlight the presence of peripheral inflammation in ALS, and more specifically, the differential monocytic gene expression profile both compared to controls and correlated to disease severity. Further interrogation of this cell population and its response to ALS-relevant stressors in vitro, by combining soluble factor analysis, proteomics, transcriptomic analysis (RNA, miRNA, circRNA), and machine-learning approaches may be particularly fruitful for the identification of novel biomarkers, or biomarker profiles, in ALS.

\section{Abbreviations}

AALS: Appel ALS score; ALS: Amyotrophic Lateral Sclerosis; ALSFRS-R: ALS Functional Rating Scale-Revised; ASO: Antisense oligonucleotides; AAV: Adeno-associated virus; BEST: Biomarker EndpointS and other Tools; CCL2: C-C Motif Chemokine Ligand 2; CMAP: Compound motor action potential; CNS: Central nervous system; CSF: Cerebrospinal fluid; CRP: Creactive protein; CXCL1: C-X-C Motif Chemokine Ligand 1; DTI: Diffusion tensor imaging; EMRs: Electronic Medical Records; EU: European Union; FDA: Food and Drug Administration; FVC: Forced Vital Capacity;

IFNY: Interferon gamma; IL: Interleukin; MCP-1 : Monocyte chemoattractant protein 1; MG: Myasthenia Gravis; miRNA: microRNA; MRI: Magnetic

Resonance Imaging; MUNIX: motor unit number index; NfL: Neurofilament light; NK cells: Natural Killer cells; NO: Nitric oxide; PBMCs: Peripheral blood mononuclear cells; PET: Positron emission tomography;

pNfH: Phosphorylated neurofilament heavy; SEB: Staphylococcal enterotoxin B; SOD1: Superoxide Dismutase; TNF: Tumor necrosis factor

\section{Acknowledgements}

Not applicable.

Authors' contributions

All authors contributed to the writing of this manuscript. All authors read and approved the final manuscript. 


\section{Funding}

Jon and Nancy Wilkins Fund for ALS research.

\section{Availability of data and materials}

Not applicable.

\section{Declarations}

\section{Ethics approval and consent to participate}

Not applicable.

\section{Consent for publication}

Not applicable.

\section{Competing interests}

The authors declare that they have no competing interests.

\section{Author details}

${ }^{1}$ Staats Life Sciences Consulting, LLC, Los Angeles, CA, USA. ²Department of Neuroscience, University of Florida College of Medicine, McKnight Brain Institute, Center for Translational Research in Neurodegenerative Disease, University of Florida, Gainesville, Florida, USA. ${ }^{3}$ Department of Neuroscience and Center for Translational Research in Neurodegenerative Disease at The University of Florida College of Medicine, Gainesville, Florida, USA. ${ }^{4}$ Department of Neurology, University of Florida College of Medicine, Gainesville, Florida, USA.

Received: 27 June 2021 Accepted: 30 December 2021

Published online: 24 January 2022

\section{References}

1. Mitsumoto $H$, Brooks BR, Silani V. Clinical trials in amyotrophic lateral sclerosis: why so many negative trials and how can trials be improved? Lancet Neurol. 2014;13(11):1127-38. https://doi.org/10.1016/S1474-4422(14 )70129-2.

2. FDA-NIH Biomarker Working Group. BEST (Biomarkers, EndpointS, and other Tools) Resource [Internet]. Silver Spring (MD): Food and Drug Administration (US); 2016 [cited 2020]. Available from: http://www.ncbi.nlm.nih.gov/books/ NBK326791/

3. Gordon PH, Moore DH, Miller RG, Florence JM, Verheijde JL, Doorish C, et al. Efficacy of minocycline in patients with amyotrophic lateral sclerosis: a phase III randomised trial. Lancet Neurol. 2007;6(12):1045-53. https://doi. org/10.1016/S1474-4422(07)70270-3

4. Amirzagar N, Nafissi S, Tafakhori A, Modabbernia A, Amirzargar A Ghaffarpour M, et al. Granulocyte Colony-stimulating factor for amyotrophic lateral sclerosis: a randomized, double-blind. Placebo-Controlled Study of Iranian Patients J Clin Neurol. 2015;11(2):164. https://doi.org/10.3988/jcn.201 5.11.2.164.

5. Urbi B, Broadley S, Bedlack R, Russo E, Sabet A. Study protocol for a randomised, double-blind, placebo-controlled study evaluating the efficacy of cannabis-based medicine extract in slowing the disease pRogression of amyotrophic lateral sclerosis or motor neurone disease: the EMERALD trial. BMJ Open. 2019;9(11):e029449. https://doi.org/10.113 6/bmjopen-2019-029449.

6. Mora JS, Genge A, Chio A, Estol CJ, Chaverri D, Hernández M, et al. Masitinib as an add-on therapy to riluzole in patients with amyotrophic lateral sclerosis: a randomized clinical trial. Amyotroph Lateral Scler Front Degener. 2020;21(1-2):5-14. https://doi.org/10.1080/21678421.2019.1632346.

7. Renton AE, Majounie E, Waite A, Simón-Sánchez J, Rollinson S, Gibbs JR, et al. A hexanucleotide repeat expansion in C9ORF72 is the cause of chromosome 9p21-linked ALS-FTD. Neuron. 2011;72(2):257-68. https://doi. org/10.1016/j.neuron.2011.09.010.

8. DeJesus-Hernandez M, Mackenzie IR, Boeve BF, Boxer AL, Baker M Rutherford NJ, et al. Expanded GGGGCC hexanucleotide repeat in noncoding region of C9ORF72 causes chromosome 9p-linked FTD and ALS. Neuron. 2011;72(2):245-56. https://doi.org/10.1016/j.neuron.2011.09.011.

9. Renton $A E$, Chiò A, Traynor BJ. State of play in amyotrophic lateral sclerosis genetics. Nat Neurosci. 2014;17(1):17-23. https://doi.org/10.1038/nn.3584

10. Bensimon $G$, Lacomblez $L$, Meininger $V$. A controlled trial of Riluzole in amyotrophic lateral sclerosis. N Engl J Med. 1994;330(9):585-91. https://doi. org/10.1056/NEJM199403033300901.
11. Arthur KC, Calvo A, Price TR, Geiger JT, Chiò A, Traynor BJ. Projected increase in amyotrophic lateral sclerosis from 2015 to 2040. Nat Commun. 2016;7(1):12408. https://doi.org/10.1038/ncomms12408.

12. Barp A, Gerardi F, Lizio A, Sansone VA, Lunetta C. Emerging drugs for the treatment of amyotrophic lateral sclerosis: a focus on recent phase 2 trials. Expert Opin Emerg Drugs. 2020;25(2):145-64. https://doi.org/10.1080/1472 8214.2020.1769067.

13. Al-Chalabi A, Hardiman O, Kiernan MC, Chiò A, Rix-Brooks B, van den Berg LH. Amyotrophic lateral sclerosis: moving towards a new classification system. Lancet Neurol. 2016;15(11):1182-94. https://doi.org/10.1016/S14 74-4422(16)30199-5.

14. Turner MR, Kiernan MC, Leigh PN, Talbot K. Biomarkers in amyotrophic lateral sclerosis. Lancet Neurol. 2009;8(1):94-109. https://doi.org/10.1016/S14 74-4422(08)70293-X

15. Shepheard SR, Wuu J, Cardoso M, Wiklendt L, Dinning PG, Chataway T, et al Urinary P75ECD: a prognostic, disease progression, and pharmacodynamic biomarker in ALS. Neurology. 2017:88(12):1137-43. https://doi.org/10.1212/ WNL.0000000000003741.

16. Rossi D, Volanti P, Brambilla L, Colletti T, Spataro R, La Bella V. CSF neurofilament proteins as diagnostic and prognostic biomarkers for amyotrophic lateral sclerosis. J Neurol. 2018;265(3):510-21. https://doi.org/1 0.1007/s00415-017-8730-6

17. Verde F, Steinacker P, Weishaupt JH, Kassubek J, Oeckl P, Halbgebauer S, et al. Neurofilament light chain in serum for the diagnosis of amyotrophic lateral sclerosis. J Neurol Neurosurg Psychiatry. 2019;90(2):157-64. https:// doi.org/10.1136/jnnp-2018-318704

18. McCombe PA, Lee JD, Woodruff TM, Henderson RD. The peripheral immune system and amyotrophic lateral sclerosis. Front Neurol. 2020;11:279. https:// doi.org/10.3389/fneur.2020.00279.

19. Philips T, Robberecht W. Neuroinflammation in amyotrophic lateral sclerosis: role of glial activation in motor neuron disease. Lancet Neurol. 2011;10(3): 253-63. https://doi.org/10.1016/S1474-4422(11)70015-1.

20. Beers DR, Appel SH. Immune dysregulation in amyotrophic lateral sclerosis: mechanisms and emerging therapies. Lancet Neurol. 2019;18(2):211-20. https://doi.org/10.1016/S1474-4422(18)30394-6.

21. Paganoni S, Macklin EA, Lee A, Murphy A, Chang J, Zipf A, et al. Diagnostic timelines and delays in diagnosing amyotrophic lateral sclerosis (ALS). Amyotroph Lateral Scler Front Degener. 2014;15(5-6):453-6. https://doi.org/1 0.3109/21678421.2014.903974.

22. Khoo A, Frasca J, Schultz D. Measuring disease activity and predicting response to intravenous immunoglobulin in chronic inflammatory demyelinating polyneuropathy. Biomark Res. 2019;7(1):3. https://doi.org/1 0.1186/s40364-019-0154-2.

23. Stino AM, Naddaf E, Dyck PJ, Dyck PJB. Chronic inflammatory demyelinating polyradiculoneuropathy_diagnostic pitfalls and treatment approach. Muscle Nerve. 2021;63(2):157-69. https://doi.org/10.1002/mus.27046.

24. Porter L, Shoushtarizadeh A, Jelinek GA, Brown CR, Lim CK, de Livera AM, et al. Metabolomic biomarkers of multiple sclerosis: a systematic review. Front Mol Biosci. 2020;7:574133. https://doi.org/10.3389/fmolb.2020.574133.

25. Rossor AM, Shy ME, Reilly MM. Are we prepared for clinical trials in CharcotMarie-tooth disease? Brain Res. 1729;2020:146625. https://doi.org/10.1016/j. brainres.2019.146625.

26. Beers DR, Zhao W, Neal DW, Thonhoff JR, Thome AD, Faridar A, et al. Elevated acute phase proteins reflect peripheral inflammation and disease severity in patients with amyotrophic lateral sclerosis. Sci Rep. 2020;10(1): 15295. https://doi.org/10.1038/s41598-020-72247-5.

27. Jin M, Günther R, Akgün K, Hermann A, Ziemssen T. Peripheral proinflammatory Th1/Th17 immune cell shift is linked to disease severity in amyotrophic lateral sclerosis. Sci Rep. 2020;10(1):5941. https://doi.org/10.103 8/s41598-020-62756-8

28. Keizman D, Rogowski O, Berliner S, Ish-Shalom M, Maimon N, Nefussy B, et al. Low-grade systemic inflammation in patients with amyotrophic lateral sclerosis. Acta Neurol Scand. 2009;119(6):383-9. https://doi.org/10.1111/j.1 600-0404.2008.01112.x

29. Tortelli R, Zecca C, Piccininni M, Benmahamed S, Dell'Abate MT, Barulli MR, et al. Plasma inflammatory cytokines are elevated in ALS. Front Neurol. 2020; 11:552295. https://doi.org/10.3389/fneur.2020.552295.

30. Mohanty L, Henderson RD, McCombe PA, Lee A. Levels of clusterin, CD5L, ficolin-3, and gelsolin in ALS patients and controls. Amyotroph Lateral Scler Front Degener. 2020:21(7-8):1-4. https://doi.org/10.1080/21678421.2020.1 779303. 
31. Polverino A, Rucco R, Stillitano I, Bonavita S, Grimaldi M, Minino R, et al. In amyotrophic lateral sclerosis blood cytokines are altered, but do not correlate with changes in brain topology. Brain Connect. 2020;10(8):411-21. https://doi.org/10.1089/brain.2020.0741.

32. Huang F, Zhu Y, Hsiao-Nakamoto J, Tang X, Dugas JC, Moscovitch-Lopatin $M$, et al. Longitudinal biomarkers in amyotrophic lateral sclerosis. Ann Clin Transl Neurol. 2020;7(7):1103-16. https://doi.org/10.1002/acn3.51078.

33. Pronto-Laborinho A, Pinto S, Gromicho M, Pereira M, Swash M, de Carvalho M. Interleukin-6 and amyotrophic lateral sclerosis. J Neurol Sci. 2019;398:503. https://doi.org/10.1016/j.jns.2019.01.026.

34. de Prado L. GR, Rocha NP, de Souza LC, Bicalho ICS, Gomez RS, VidigalLopes $\mathrm{M}$, et al. Longitudinal assessment of clinical and inflammatory markers in patients with amyotrophic lateral sclerosis J Neurol Sci. 2018;394: 69-74. https://doi.org/10.1016/j.jns.2018.08.033

35. Andrés-Benito P, Moreno J, Domínguez R, Aso E, Povedano M, Ferrer I. Inflammatory gene expression in whole peripheral blood at early stages of sporadic amyotrophic lateral sclerosis. Front Neurol. 2017:8:546. https://doi. org/10.3389/fneur.2017.00546.

36. Sheinerman KS, Toledo JB, Tsivinsky VG, Irwin D, Grossman M, Weintraub D, et al. Circulating brain-enriched microRNAs as novel biomarkers for detection and differentiation of neurodegenerative diseases. Alzheimers Res Ther. 2017;9(1):89. https://doi.org/10.1186/s13195-017-0316-0.

37. Pronto-Laborinho AC. Gromicho M, Pereira M, Pinto S, Barros M do a, Swash $\mathrm{M}$, et al. plasma level of club-cell (CC-16) predicts outcome in amyotrophic lateral sclerosis. Acta Neurol Scand. 2018;137(2):233-7. https://doi.org/1 0.1111 /ane.12851.

38. Hu Y, Cao C, Qin X-Y, Yu Y, Yuan J, Zhao Y, et al. Increased peripheral blood inflammatory cytokine levels in amyotrophic lateral sclerosis: a meta-analysis study. Sci Rep. 2017;7(1):9094. https://doi.org/10.1038/s41598-017-09097-1.

39. Blasco H, Garcon G, Patin F, Veyrat-Durebex C, Boyer J, Devos D, et al. Panel of oxidative stress and inflammatory biomarkers in ALS: a pilot study. Can J Neurol Sci J Can Sci Neurol. 2017:44(1):90-5. https://doi.org/10.1017/cjn.201 6.284

40. Italiani $\mathrm{P}$, Carlesi $\mathrm{C}$, Giungato $\mathrm{P}$, Puxeddu I, Borroni B, Bossù $\mathrm{P}$, et al. Evaluating the levels of interleukin-1 family cytokines in sporadic amyotrophic lateral sclerosis. J Neuroinflammation. 2014;11(1):94. https://doi. org/10.1186/1742-2094-11-94

41. Lin CY, Pfluger CM, Henderson RD, McCombe PA. Reduced levels of interleukin 33 and increased levels of soluble ST2 in subjects with amyotrophic lateral sclerosis. J Neuroimmunol. 2012;249(1-2):93-5. https:// doi.org/10.1016/j.jneuroim.2012.05.001.

42. Fiala M, Chattopadhay M, La Cava A, Tse E, Liu G, Lourenco E, et al. IL-17A is increased in the serum and in spinal cord CD8 and mast cells of ALS patients. J Neuroinflammation. 2010;7(1):76. https://doi.org/10.1186/1742-2 094-7-76.

43. Chen Y, Stankovic R, Cullen KM, Meininger V, Garner B, Coggan S, et al. The kynurenine pathway and inflammation in amyotrophic lateral sclerosis. Neurotox Res. 2010;18(2):132-42. https://doi.org/10.1007/s12640-009-9129-7.

44. Kuhle J, Lindberg RLP, Regeniter A, Mehling M, Steck AJ, Kappos L, et al. Increased levels of inflammatory chemokines in amyotrophic lateral sclerosis. Eur J Neurol. 2009;16(6):771-4. https://doi.org/10.1111/j.14 68-1331.2009.02560.x.

45. Babu GN, Kumar A, Chandra R, Puri SK, Kalita J, Misra UK. Elevated inflammatory markers in a Group of Amyotrophic Lateral Sclerosis Patients from northern India. Neurochem Res. 2008;33(6):1145-9. https://doi.org/10.1 007/s11064-007-9564-x

46. Rentzos M, Nikolaou C, Rombos A, Boufidou F, Zoga M, Dimitrakopoulos A, et al. RANTES levels are elevated in serum and cerebrospinal fluid in patients with amyotrophic lateral sclerosis. Amyotroph Lateral Scler. 2007; 8(5):283-7. https://doi.org/10.1080/17482960701419232.

47. Baron P, Bussini S, Cardin V, Corbo M, Conti G, Galimberti D, et al. Production of monocyte chemoattractant protein-1 in amyotrophic lateral sclerosis. Muscle Nerve. 2005;32(4):541-4. https://doi.org/10.1002/ mus.20376.

48. Wilms $\mathrm{H}$. Intrathecal synthesis of monocyte chemoattractant protein-1 (MCP-1) in amyotrophic lateral sclerosis: further evidence for microglia activation in neurodegeneration. J Neuroimmunol. 2003;144(1-2):139-42. https://doi.org/10.1016/j.jneuroim.2003.08.042

49. Etzrodt M, Cortez-Retamozo V, Newton A, Zhao J, Ng A, Wildgruber M, et al. Regulation of monocyte functional heterogeneity by miR-146a and Relb. Cell Rep. 2012;1(4):317-24. https://doi.org/10.1016/j.celrep.2012.02.009.
50. Banack SA, Dunlop RA, Cox PA. An miRNA fingerprint using neural-enriched extracellular vesicles from blood plasma: towards a biomarker for amyotrophic lateral sclerosis/motor neuron disease. Open Biol. 2020;10(6): 200116. https://doi.org/10.1098/rsob.200116.

51. Xu Z, Lee A, Nouwens A, Henderson RD, McCombe PA. Mass spectrometry analysis of plasma from amyotrophic lateral sclerosis and control subjects. Amyotroph Lateral Scler Front Degener. 2018;19(5-6):362-76. https://doi. org/10.1080/21678421.2018.1433689.

52. McCauley ME, O'Rourke JG, Yáñez A, Markman JL, Ho R, Wang X, et al. C9orf72 in myeloid cells suppresses STING-induced inflammation. Nature. 2020;585(7823):96-101. https://doi.org/10.1038/s41586-020-2625-x.

53. Perner C, Perner F, Stubendorff B, Förster M, Witte OW, Heidel FH, et al. Dysregulation of chemokine receptor expression and function in leukocytes from ALS patients. J Neuroinflammation. 2018;15(1):99. https://doi.org/10.11 86/s12974-018-1135-3.

54. Rusconi M, Gerardi F, Santus W, Lizio A, Sansone VA, Lunetta C, et al. Inflammatory role of dendritic cells in amyotrophic lateral sclerosis revealed by an analysis of patients' peripheral blood. Sci Rep. 2017;7(1):7853. https:// doi.org/10.1038/s41598-017-08233-1.

55. Gustafson MP, Staff NP, Bornschlegl S, Butler GW, Maas ML, Kazamel M, et al Comprehensive immune profiling reveals substantial immune system alterations in a subset of patients with amyotrophic lateral sclerosis. Raoul C, editor. PLOS ONE. 2017;12:e0182002.

56. Zhao W, Beers DR, Hooten KG, Sieglaff DH, Zhang A, Kalyana-Sundaram S, et al. Characterization of gene expression phenotype in amyotrophic lateral sclerosis monocytes. JAMA Neurol. 2017;74(6):677-85. https://doi.org/10.1 001/jamaneurol.2017.0357

57. Lam L, Chin L, Halder RC, Sagong B, Famenini S, Sayre J, et al. Epigenetic changes in T-cell and monocyte signatures and production of neurotoxic cytokines in ALS patients. FASEB J Off Publ Fed Am Soc Exp Biol. 2016; 30(10):3461-73. https://doi.org/10.1096/fj.201600259RR.

58. Saresella M, Piancone F, Tortorella P, Marventano I, Gatti A, Caputo D, et al. Thelper-17 activation dominates the immunologic milieu of both amyotrophic lateral sclerosis and progressive multiple sclerosis. Clin Immunol. 2013;148(1):79-88. https://doi.org/10.1016/j.clim.2013.04.010.

59. Fiala M, Mizwicki MT, Weitzman R, Magpantay L, Nishimoto N. Tocilizumab infusion therapy normalizes inflammation in sporadic ALS patients. Am J Neurodegener Dis. 2013;2(2):129-39.

60. Mizwicki MT, Fiala M, Magpantay L, Aziz N, Sayre J, Liu G, et al. Tocilizumab attenuates inflammation in ALS patients through inhibition of IL6 receptor signaling. Am J Neurodegener Dis. 2012;1(3):305-15.

61. Zhang R, Gascon R, Miller RG, Gelinas DF, Mass J, Hadlock K, et al. Evidence for systemic immune system alterations in sporadic amyotrophic lateral sclerosis (sALS). J Neuroimmunol. 2005;159(1-2):215-24. https://doi.org/10.1 016/j.jneuroim.2004.10.009.

62. Olsson A, Gustavsen S, Gisselø Lauridsen K, Chenoufi Hasselbalch I, Sellebjerg F, Bach Søndergaard $\mathrm{H}$, et al. Neutrophil-to-lymphocyte ratio and CRP as biomarkers in multiple sclerosis: a systematic review. Acta Neurol Scand. 2021;143(6):577-86. https://doi.org/10.1111/ane.13401.

63. Gururaj S, Sampognaro PJ, Argouarch AR, Kao AW. Progranulin adsorbs to polypropylene tubes and disrupts functional assays: implications for research, biomarker studies, and therapeutics. Front Neurosci. 2020;14: 602235. https://doi.org/10.3389/fnins.2020.602235.

64. Benatar M, Boylan K, Jeromin A, Rutkove SB, Berry J, Atassi N, et al. ALS biomarkers for therapy development: state of the field and future directions. Muscle Nerve. 2016;53(2):169-82. https://doi.org/10.1002/mus.24979.

65. Gaur N, Huss E, Prell T, Steinbach R, Guerra J, Srivastava A, et al. Monocytederived macrophages contribute to Chitinase dysregulation in amyotrophic lateral sclerosis: a pilot study. Front Neurol. 2021;12:629332. https://doi.org/1 $0.3389 /$ fneur.2021.629332.

66. . . F. https://www.fda.gov/regulatory-information/search-fda-guidancedocuments/amyotrophic-lateral-sclerosis-developing-drugs-treatment-guida nce-industry.

67. Sun J, Carrero JJ, Zagai U, Evans M, Ingre C, Pawitan Y, et al. Blood biomarkers and prognosis of amyotrophic lateral sclerosis. Eur J Neurol. 2020;27(11):2125-33. https://doi.org/10.1111/ene.14409.

68. Bendotti C, Bonetto V, Pupillo E, Logroscino G, Al-Chalabi A, Lunetta C, et al. Focus on the heterogeneity of amyotrophic lateral sclerosis. Amyotroph Lateral Scler Front Degener. 2020:1-11.

69. Lunetta C, Lizio A, Maestri E, Sansone VA, Mora G, Miller RG, et al Serum C-reactive protein as a prognostic biomarker in amyotrophic 
lateral sclerosis. JAMA Neurol. 2017;74(6):660-7. https://doi.org/10.1001/ja maneurol.2016.6179.

70. Devos D, Moreau C, Kyheng M, Garçon G, Rolland AS, Blasco H, et al. A ferroptosis-based panel of prognostic biomarkers for amyotrophic lateral sclerosis. Sci Rep. 2019;9(1):2918. https://doi.org/10.1038/s41598-019-39739-5.

71. Liu G, Fiala M, Mizwicki MT, Sayre J, Magpantay L, Siani A, et al. Neuronal phagocytosis by inflammatory macrophages in ALS spinal cord: inhibition of inflammation by resolvin D1. Am J Neurodegener Dis. 2012;1 (1):60-74.

72. Miller RG, Zhang R, Block G, Katz J, Barohn R, Kasarskis E, et al. NP001 regulation of macrophage activation markers in ALS: a phase I clinical and biomarker study. Amyotroph Lateral Scler Front Degener. 2014;15(7-8):6019. https://doi.org/10.3109/21678421.2014.951940.

73. Henkel JS, Beers DR, Wen S, Rivera AL, Toennis KM, Appel JE, et al. Regulatory T-lymphocytes mediate amyotrophic lateral sclerosis progression and survival. EMBO Mol Med. 2013;5(1):64-79. https://doi.org/10.1002/ emmm.201201544.

74. Haverkamp $L$, Appel V, Appel SH. Natural history of amyotrophic lateral sclerosis in a database population. Validation of a scoring system and a model for survival prediction. Brain J Neurol. 1995;118(Pt 3):707-19. https:// doi.org/10.1093/brain/118.3.707

75. van Eijk RPA, Westeneng H-J, Nikolakopoulos S, Verhagen IE, van Es MA, Eijkemans MJC, et al. Refining eligibility criteria for amyotrophic lateral sclerosis clinical trials. Neurology. 2019;92(5):e451-60. https://doi.org/1 0.1212 WNL.0000000000006855.

76. Westeneng H-J, Debray TPA, Visser AE, van Eijk RPA, Rooney JPK, Calvo A, et al. Prognosis for patients with amyotrophic lateral sclerosis: development and validation of a personalised prediction model. Lancet Neurol. 2018; 17(5):423-33. https://doi.org/10.1016/S1474-4422(18)30089-9.

77. Benatar M, Turner MR, Wuu J. Defining pre-symptomatic amyotrophic lateral sclerosis. Amyotroph Lateral Scler Front Degener. 2019;20(5-6):303-9. https://doi.org/10.1080/21678421.2019.1587634.

78. Wainberg M, Magis AT, Earls JC, Lovejoy JC, Sinnott-Armstrong N, Omenn GS, et al. Multiomic blood correlates of genetic risk identify presymptomatic disease alterations. Proc Natl Acad Sci. 2020;117(35):21813-20. https://doi. org/10.1073/pnas.2001429117.

79. Wang H, Shen X, Li J, Suckling J, Tan C, Wang Y, et al. Clinical and biomarker trajectories in sporadic Alzheimer's disease: A longitudinal study. Alzheimers Dement Diagn Assess Dis Monit. 2020;12 Available from: https:// onlinelibrary.wiley.com/doi/10.1002/dad2.12095. Cited 2021 Feb 20.

80. Benatar M, Wuu J, Andersen PM, Lombardi V, Malaspina A. Neurofilament light: a candidate biomarker of presymptomatic amyotrophic lateral sclerosis and phenoconversion. Ann Neurol. 2018;84(1):130-9. https://doi. org/10.1002/ana.25276.

81. van den Berg LH, Sorenson E, Gronseth G, Macklin EA, Andrews J, Baloh RH, et al. Revised Airlie house consensus guidelines for design and implementation of ALS clinical trials. Neurology. 2019;92(14):e1610-23. https://doi.org/10.1212/WNL.0000000000007242

82. Kiernan MC, Vucic S, Talbot K, McDermott CJ, Hardiman O, Shefner JM, et al. Improving clinical trial outcomes in amyotrophic lateral sclerosis. Nat Rev Neurol. 2021;17(2):104-18. https://doi.org/10.1038/s41582-020-00434-z.

83. Baumert B, Sobuś A, Gołąb-Janowska M, Paczkowska E, Łuczkowska K, Rogińska $D$, et al. Repeated application of autologous bone marrow-derived lineagenegative stem/progenitor cells_-focus on immunological pathways in patients with ALS. Cells. 2020;9(8):1822. https:/doi.org/10.3390/cells9081822.

84. Milligan C, Atassi N, Babu S, Barohn RJ, Caress JB, Cudkowicz ME, et al. Tocilizumab is safe and tolerable and reduces $C$-reactive protein concentrations in the plasma and cerebrospinal fluid of ALS patients. Muscle Nerve. 2021;64(3):309-20. https://doi.org/10.1002/mus.27339.

85. Rosenfeld J. Rethinking amyotrophic lateral sclerosis. Mayo Clin Proc. 2018; 93(11):1543-5. https://doi.org/10.1016/j.mayocp.2018.09.009.

86. Pichler WJ. Adverse side-effects to biological agents. Allergy. 2006;61(8):91220. https://doi.org/10.1111/j.1398-9995.2006.01058.x.

87. Bugelski PJ, Achuthanandam R, Capocasale RJ, Treacy G, Bouman-Thio E. Monoclonal antibody-induced cytokine-release syndrome. Expert Rev Clin Immunol. 2009;5(5):499-521. https://doi.org/10.1586/eci.09.31.

88. Miller T, Cudkowicz M, Shaw PJ, Andersen PM, Atassi N, Bucelli RC, et al. Phase 1-2 trial of antisense oligonucleotide Tofersen for SOD1 ALS. N Engl J Med. 2020;383(2):109-19. https://doi.org/10.1056/NEJMoa2003715.

89. Delhaas EM, Huygen FJPM. Complications associated with intrathecal drug delivery systems. BJA Educ. 2020;20(2):51-7. https://doi.org/10.1016/j.bjae.2 019.11.002.
90. O'Brien SM, Cunningham CC, Golenkov AK, Turkina AG, Novick SC, Rai KR. Phase I to II multicenter study of Oblimersen sodium, a BCl-2 antisense oligonucleotide, in patients with advanced chronic lymphocytic leukemia. J Clin Oncol. 2005;23(30):7697-702. https://doi.org/10.1200/JCO.2005.02.4364.

91. Perez BA, Shutterly A, Chan YK, Byrne BJ, Corti M. Management of Neuroinflammatory Responses to AAV-mediated gene therapies for neurodegenerative diseases. Brain Sci. 2020;10(2):119. https://doi.org/10.33 90/brainsci10020119.

92. Je G, Keyhanian K, Ghasemi M. Overview of stem cells therapy in amyotrophic lateral sclerosis. Neurol Res. 2021;43(8):1-17. https://doi.org/1 $0.1080 / 01616412.2021 .1893564$

93. Research C for BE and. Update on Amyotrophic Lateral Sclerosis (ALS) Product Development. FDA. FDA; 2021. Available from: https://www.fda. gov/vaccines-blood-biologics/cellular-gene-therapy-products/update-a myotrophic-lateral-sclerosis-als-product-development. Cited 2021 Apr 7.

94. Miller RG, Block G, Katz JS, Barohn RJ, Gopalakrishnan V, Cudkowicz M, et al. Randomized phase 2 trial of NP001-a novel immune regulator: safety and early efficacy in ALS. Neurol Neuroimmunol Neuroinflammation. 2015;2(3): e100. https://doi.org/10.1212/NXI.0000000000000100.

95. Schafflick D, Xu CA, Hartlehnert M, Cole M, Schulte-Mecklenbeck A, Lautwein $T$, et al. Integrated single cell analysis of blood and cerebrospinal fluid leukocytes in multiple sclerosis. Nat Commun. 2020;11(1):247. https:// doi.org/10.1038/s41467-019-14118-w.

96. Raheja R, Regev K, Healy BC, Mazzola MA, Beynon V, Von Glehn F, et al. Correlating serum micrornas and clinical parameters in amyotrophic lateral sclerosis. Muscle Nerve. 2018;58(2):261-9. https://doi.org/10.1002/mus.26106.

97. Liguori M, Nuzziello N, Introna A, Consiglio A, Licciulli F, D'Errico E, et al. Dysregulation of MicroRNAs and target genes networks in peripheral blood of patients with sporadic amyotrophic lateral sclerosis. Front Mol Neurosci. 2018;11:288. https://doi.org/10.3389/fnmol.2018.00288.

98. Waller R, Goodall EF, Milo M, Cooper-Knock J, Da Costa M, Hobson E, et al. Serum miRNAs miR-206, 143-3p and 374b-5p as potential biomarkers for amyotrophic lateral sclerosis (ALS). Neurobiol Aging. 2017;55:123-31. https:// doi.org/10.1016/j.neurobiolaging.2017.03.027.

99. Henshall DC, Hamer HM, Pasterkamp RJ, Goldstein DB, Kjems J, Prehn JHM, et al. MicroRNAs in epilepsy: pathophysiology and clinical utility. Lancet Neurol. 2016;15(13):1368-76. https://doi.org/10.1016/S1474-4422(16)30246-0.

100. Dolinar A, Koritnik B, Glavač D, Ravnik-Glavač M. Circular RNAs as potential blood biomarkers in amyotrophic lateral sclerosis. Mol Neurobiol. 2019; 56(12):8052-62. https://doi.org/10.1007/s12035-019-1627-x.

101. Yang J, Diaz N, Adelsberger J, Zhou X, Stevens R, Rupert A, et al. The effects of storage temperature on PBMC gene expression. BMC Immunol. 2016; 17(1):6. https://doi.org/10.1186/s12865-016-0144-1.

102. Hu WT, Trojanowski JQ, Shaw LM. Biomarkers in frontotemporal lobar degenerations-Progress and challenges. Prog Neurobiol. 2011;95(4):63648. https://doi.org/10.1016/.jpneurobio.2011.04.012.

103. Poste G. Bring on the biomarkers. Nature. 2011;469(7329):156-7. https://doi. org/10.1038/469156a.

\section{Publisher's Note}

Springer Nature remains neutral with regard to jurisdictional claims in published maps and institutional affiliations.

Ready to submit your research? Choose BMC and benefit from:

- fast, convenient online submission

- thorough peer review by experienced researchers in your field

- rapid publication on acceptance

- support for research data, including large and complex data types

- gold Open Access which fosters wider collaboration and increased citations

- maximum visibility for your research: over $100 \mathrm{M}$ website views per year

At $\mathrm{BMC}$, research is always in progress.

Learn more biomedcentral.com/submission 